\title{
The Mejillonia suspect terrane (Northern Chile): Late Triassic fast burial and metamorphism of sediments in a magmatic arc environment extending into the Early Jurassic
}

\author{
C. Casquet $^{\text {a,* }}$, F. Hervé ${ }^{\text {b,c }}$, R.J. Pankhurst ${ }^{\text {d }}$, E. Baldo ${ }^{\text {e }}$, M. Calderón ${ }^{f}$, C.M. Fanning ${ }^{g}$, \\ C.W. Rapela ${ }^{\text {h }}$ J. Dahlquist ${ }^{\mathrm{e}}$
}

a Departamento de Petrología y Geoquímica, Universidad Complutense - Instituto de Geociencias (UCM, CSIC), 28040 Madrid, Spain

${ }^{\mathrm{b}}$ Departamento de Geología, Universidad de Chile, Plaza Ercilla 803, Santiago, Chile

' Escuela de Ciencias de la Tierra, Universidad Andres Bello, Sazie 2315, Santiago, Chile

d Visiting Research Associate, British Geological Survey, Keyworth, Nottingham NG12 5GG, United Kingdom

e CICTERRA-CONICET-UNC, Av. Vélez Sarsfield 1611, Pab. Geol., X5016CGA Córdoba, Argentina

${ }^{\mathrm{f}}$ Servicio Nacional de Geología y Minería, Santa Maria 0104, Santiago, Chile

${ }^{g}$ Research School of Earth Sciences, The Australian National University, Canberra, ACT 0200, Australia

${ }^{\mathrm{h}}$ Centro de Investigaciones Geológicas (CONICET-UNLP), 1900 La Plata, Argentina

\section{A R T I C L E I N F O}

\section{Article history}

Received 14 March 2013

Received in revised form 7 May 2013

Accepted 14 May 2013

Available online 10 June 2013

Handling Editor: R.D. Nance

Keywords:

Mejillonia terrane

U-Pb SHRIMP zircon geochronology

Pre-Andean continental margin

Late Triassic subduction

Early Jurassic magmatic arc

\begin{abstract}
A B S T R A C T
The Mejillonia terrane, named after the Mejillones Peninsula (northern Chile), has been traditionally considered an early Paleozoic block of metamorphic and igneous rocks displaced along the northern Andean margin in the Mesozoic. However, U-Pb SHRIMP zircon dating of metasedimentary and igneous rocks shows that the sedimentary protoliths were Triassic, and that metamorphism and magmatism took place in the Late Triassic (Norian). Field evidence combined with zircon dating (detrital and metamorphic) further suggests that the sedimentary protoliths were buried, deformed (foliated and folded) and metamorphosed very rapidly, probably within few million years, at ca. $210 \mathrm{Ma}$. The metasedimentary wedge was then uplifted and intruded by a late arc-related tonalite body (Morro Mejillones) at $208 \pm 2 \mathrm{Ma}$, only a short time after the peak of metamorphism. The Mejillones metamorphic and igneous basement represents an accretionary wedge or marginal basin that underwent contractional deformation and metamorphism at the end of a Late Permian to Late Triassic anorogenic episode that is well known in Chile and Argentina. Renewal of subduction along the pre-Andean continental margin in the Late Triassic and the development of new subduction-related magmatism are probably represented by the Early Jurassic Bólfin-Punta Tetas magmatic arc in the southern part of the peninsula, for which an age of $184 \pm 1$ Ma was determined. We suggest retaining the classification of Mejillonia as a tectonostratigraphic terrane, albeit in this new context.
\end{abstract}

(C) 2013 International Association for Gondwana Research. Published by Elsevier B.V. All rights reserved.

\section{Introduction}

Active continental margins of Andean or Cordilleran type are accretionary orogens in the sense of Cawood et al. (2003, 2009), where a complex interplay occurs between accretionary processes s.l. and tectonic erosion along the subduction zone (e.g., Stern, 2011). Accretion embraces, on the one hand, subduction-related, mantle-derived, arc magmatism that contributes to the long-term growth of the continental crust and, on the other hand, the construction of accretionary wedges along the active margin front and the amalgamation of suspect terranes (for a review of terrane nomenclature see Gibbons, 1994). The latter are typically either displaced along the margin as a result of oblique subduction (transcurrent terranes), or are exotic to it (e.g., buoyant oceanic

\footnotetext{
* Corresponding author. Tel.: + 34 913944908; fax: + 34915442535.

E-mail address: casquet@geo.ucm.es (C. Casquet).
}

plateaux, ridges, or continental blocks). Because of its contribution to the overall growth of the active continental margin and its importance to understanding the geodynamic evolution of the orogen, a suspect terrane must be thoroughly surveyed before its identity is proven. Techniques such as SHRIMP U-Pb dating of detrital zircons in rocks with sedimentary protoliths have proved particularly useful in this regard, especially in cases where the suspect terrane is metamorphic and chronostratigraphy is obscured by deformation and recrystallization.

The proto-Andean margin of the supercontinent Gondwana in southern South America is universally interpreted as resulting from terrane accretion. Here a collage of allochthonous terranes, some allegedly exotic, has been widely accepted since the seminal contribution of Ramos (1988). These terranes were accreted to the protoAndean margin throughout the Paleozoic and are now exposed in the basement of the Andes and in the Andean foreland in Chile and Argentina. Moreover, terrane accretion continued along the Andean 
margin in the early Mesozoic, exemplified by the metamorphic and plutonic terrane that constitutes the elongated Mejillones Peninsula north of Antofagasta (Fig. 1). This was first considered a terrane by Ramos (1988; Fig. 1) and allegedly docked to the Chilean margin in Jurassic time (Damm et al., 1990), probably through protracted sinistral strike-slip movements along the Atacama fault system that continued into the Middle Cretaceous (Brown et al., 1993; Bahlburg and Hervé, 1997).

The concept of the Mejillonia terrane was first based on the idea that it contains anomalously old rocks for its situation on the Andean margin. Whereas the basement of coastal Chile elsewhere at these latitudes is represented by low-grade metasedimentary rocks of probable Devonian age, several authors using a variety of geochronological methods (see details below) have claimed ages of ca. 500 Ma for igneous and metamorphic rocks from the Mejillones Peninsula (Damm et al., 1990). Significant in this regard is the fact that Cambrian plutonism and metamorphism are typical of the collisional Pampean orogeny in Argentina (e.g., Rapela et al., 1998) some $700 \mathrm{~km}$ east of the Pacific coast. This orogeny has been recently considered a segment of a longer mainland orogenic belt extending northward into Paraguay and Brazil along the eastern margin of the Proterozoic Amazonia craton (the Paraguay and Araguaia mobile belts). Since this is far removed from

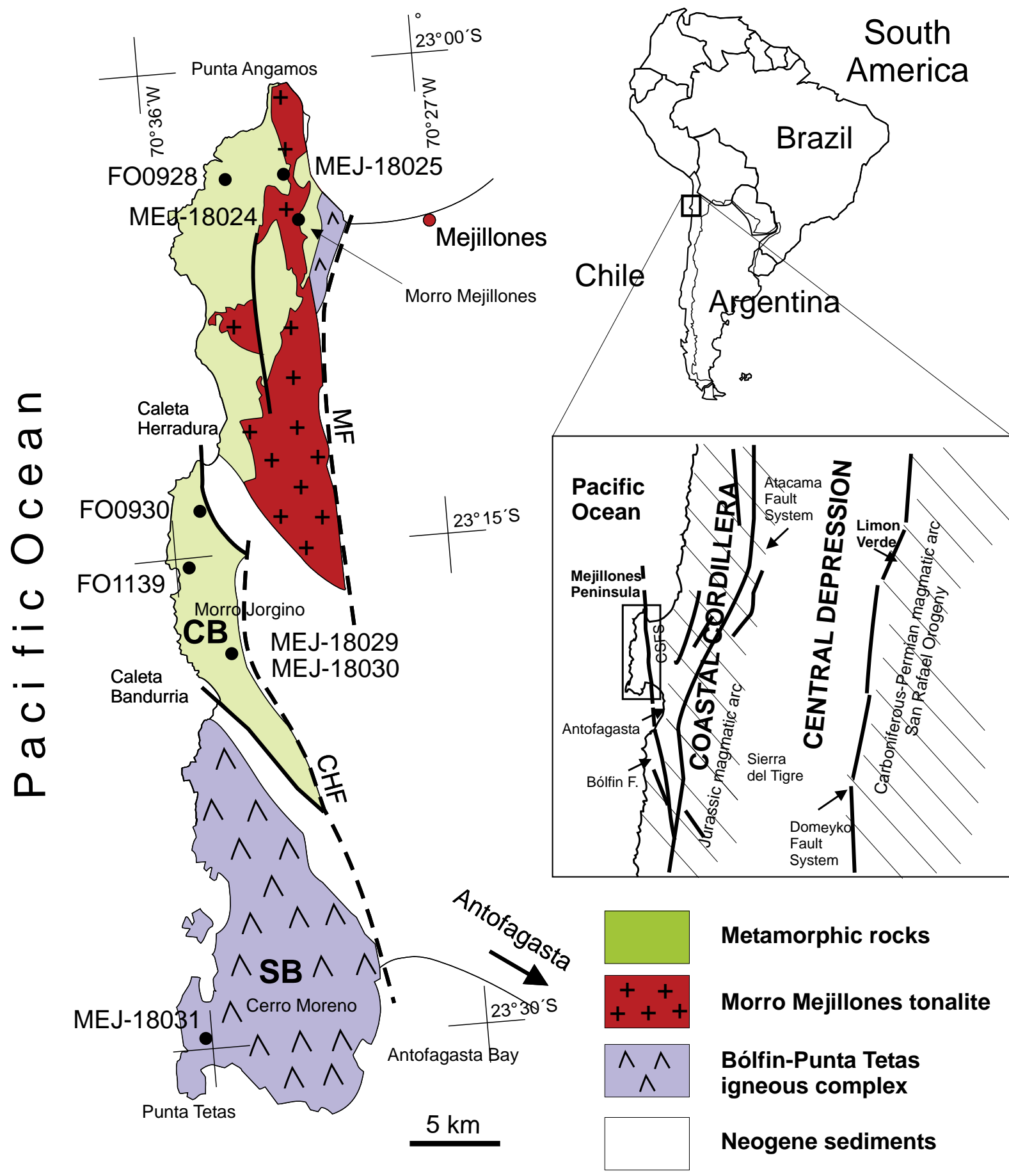

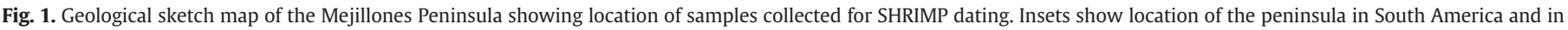

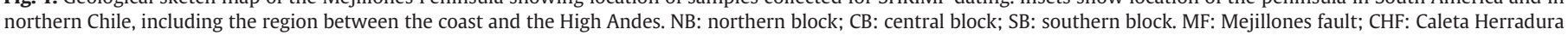
fault (Cortés et al., 2008). 
the Pacific coast (Casquet et al., 2012), Cambrian metamorphic rocks would not be expected west of the Pampean belt. The Mejillonia terrane consequently poses an intriguing problem with respect to the geography of the Cambrian orogeny that led to the final amalgamation of SW Gondwana (Casquet et al., 2012 and references therein).

The aim of this paper is to present new geochronological data on metamorphic and intrusive rocks of the Mejillones peninsula, obtained by SHRIMP analysis of zircons (a method not previously employed on these rocks) in order to constrain their geological and geodynamic significances.

\section{Geological setting}

The Coastal Cordillera of northern Chile is mainly composed of Mesozoic volcanic and plutonic rocks, which testify to the existence since Jurassic times of a magmatic arc related to east-directed subduction. Deep parts of the Jurassic magmatic arc are exposed south of Antofagasta (e.g., Bólfin Formation) and in the Mejillones Peninsula (Punta Tetas) (Fig. 1).

The Mejillones Peninsula is the largest along the North Chilean coast. It is formed of igneous and metamorphic rocks that constitute a $\mathrm{N}-\mathrm{S}$ elongate massif, separated from the mainland by a low area of Neogene marine sediments that are in fault contact with the igneous and metamorphic rocks (Figs. 1 and 2). The peninsula consists of three geologically contrasting blocks (Baeza, 1984) resulting from Cenozoic extensional uplift along normal faults (horst and graben structures) (Niemeyer et al., 1996; Hartley et al., 2000) (Figs. 1 and 2 ). According to Baeza (1984), the northern block is formed of metapelitic rocks that exhibit mineral zonation - biotite, andalusite and sillimanite zones - related to the plutonic body of Morro Mejillones. The central Morro Jorgino block is composed of amphibolites and metapelites with a garnet, kyanite, sillimanite mineral zonation (i.e., a Barrovian-type metamorphism), whereas the southern Cerro Moreno block is composed of dioritic to gabbroic plutons of the Bólfin-Punta Tetas complex.

The Morro Mejillones pluton is an elongate N-S body consisting of coarse-grained biotite-hornblende tonalite, with igneous contacts discordant to the structural trend of the host rocks, and with many apophyses. The host rocks are gneisses and schists with a few metapsammitic layers, showing two phases of foliation and folding. $\mathrm{S}_{0}-\mathrm{S}_{1}$ is a compositional banding represented by alternating thicker quartz-rich and thinner biotite-rich layers. Folds are isoclinal and east-vergent, and near the axial zone show a foliation $\left(\mathrm{S}_{2}\right)$ that overprints $\mathrm{S}_{0}-\mathrm{S}_{1}$. An intersection lineation is common. Foliations and

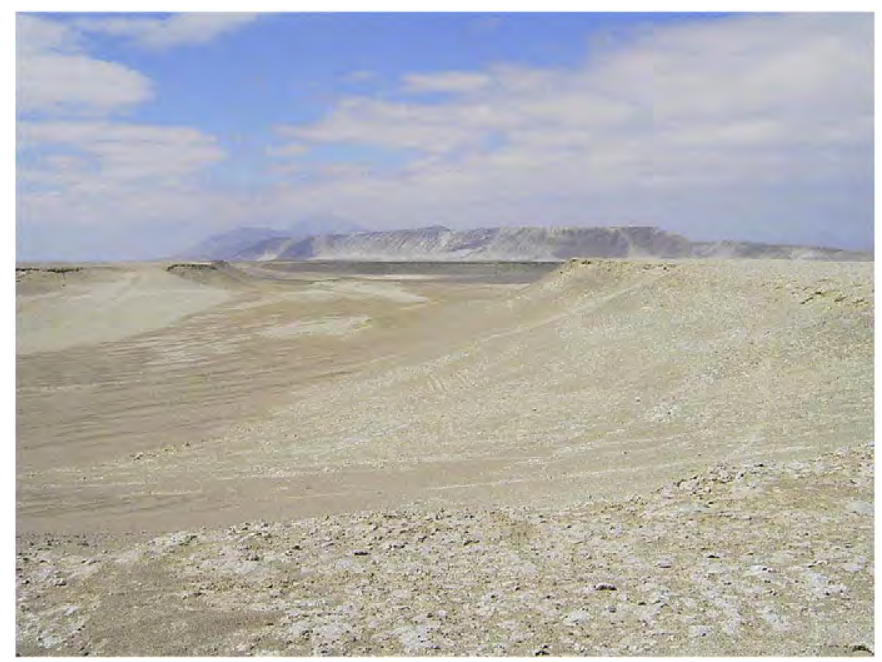

Fig. 2. View of the Mejillones relief from the north. Uplifted basement blocks (horsts) are bounded by normal fault scarps and are topped by marine terraces. Neogene marine sediments fill the depression (graben) in the foreground. folding developed before pluton emplacement. The pluton does not extend into the central block, where the rocks are again banded gneisses and schists with deformed quartz veins, and amphibolites and garnet leucogranite sheets concordant or slightly discordant to the external foliation (Fig. 3). The southern block consists mainly of intermediate to basic plutonic rocks with an earlier, probably primary, foliation/lineation and superimposed mylonitization that varies from weak to strong.

The inland Paleozoic rocks of this region have been considered to form part of an accretionary prism, which developed mainly from Devonian through to Permian times (e.g., Bahlburg et al., 2009). These units are mainly composed of low-grade metamorphic rocks with predominant turbiditic protoliths, and scarce basic rocks and limestones. The higher metamorphic grade of the rocks of Mejillones Peninsula, and of those of the Limon Verde metamorphic complex east of the Atacama fault system at this latitude (Fig. 1), has been an obstacle for their consideration as an integral part of the accretionary prism. The Limon Verde rocks have been considered to belong to an intercontinental mobile belt (Lucassen et al., 2000), and the Mejillones metamorphic rocks to a tectono-stratigraphic terrane. However, Tomlinson et al. (2012) have argued, by geological analogy with the Laramide orogeny, that the Limon Verde metamorphic rocks are typical of accretionary complexes and that they record flat-slab subduction during the early to middle-Permian San Rafael phase of the Gondwanide orogeny (Fig. 1). Hervé and Mpodozis (1990), in a survey of the previously suggested terranes on the western margin of Gondwana, refer to the Mejillonia terrane as one whose age and timing of docking to Gondwana are unknown.

The basement rocks of the Mejillones Peninsula have been subjected to extensive previous geochronological study, albeit mostly in the last decades of the twentieth century. Initially, Diaz et al. (1985) presented $\mathrm{Rb}-\mathrm{Sr}$ whole rock (WR) data for samples of andalusite-zone schists at Punta Angamos in the northern block, which were claimed to give a reference isochron of $530 \mathrm{Ma}$. Damm et al. (1990) obtained an imprecise Sm-Nd WR age of $521 \pm 55$ Ma for orthoamphibolite from a central outcrop (Morro Jorgino), and Lucassen et al. (2000) obtained an age of $525 \pm 10$ Ma from a Sm-Nd mineral isochron from a Morro Jorgino garnet amphibolite. These Early Paleozoic (ca. $500 \mathrm{Ma}$ ) ages served as the basis for interpreting the Mejillones Peninsula as an old terrane accreted to the Andean margin in the Jurassic (Damm et al., 1990; Bahlburg and Hervé, 1997).

Jurassic ages of ca. 190 Ma have been recorded from igneous rocks of the Bólfin-Punta Tetas complex in the southern block (Cerro Moreno) (Damm et al., 1986; reported by Cortés et al., 2007). In addition, K-Ar ages on muscovite, biotite and amphibole from the metamorphic and

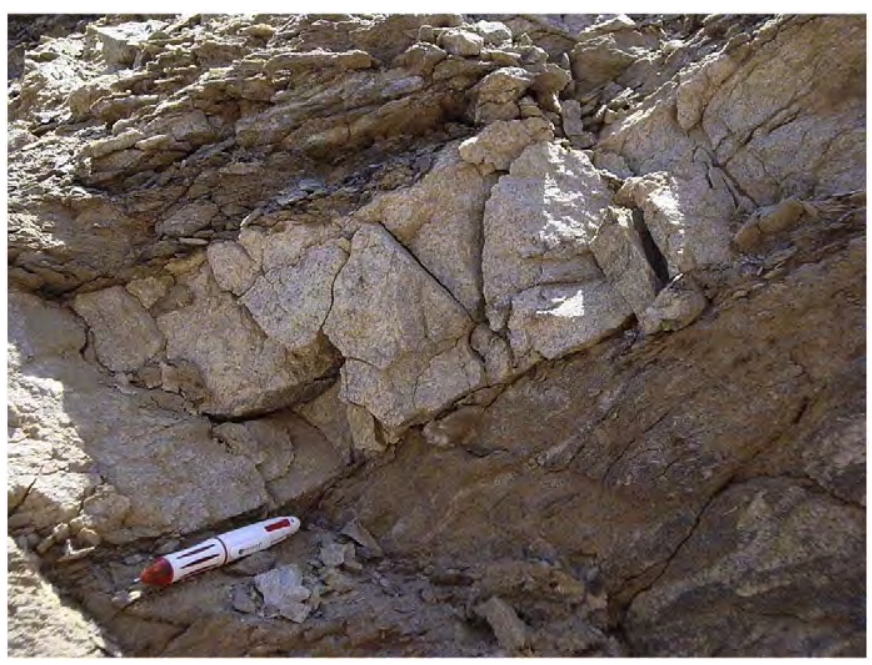

Fig. 3. Outcrop view of garnet-bearing leucogranite MEJ-18029. For explanation see text 
igneous rocks (Basei et al., 1996; Diaz et al., 1985; Lucassen et al., 2000) generally range from 140 to $190 \mathrm{Ma}$, pointing to thermal effects throughout the Jurassic that are probably related to emplacement of the Bólfin-Punta Tetas pluton.

Hervé et al. (2010) obtained detrital zircon U-Pb SHRIMP age patterns for two low-grade metasedimentary rocks relevant to the current work: F00928 from the Mejillones Peninsula (full data are presented for the first time here) and an amphibolite facies rock from the Limón Verde complex. The detrital age pattern of F00928 shows mainly Early Paleozoic ages and a significant number is in the range 1000-1200 Ma. In contrast, the Limon Verde mica schist displays predominant Early Permian detrital zircons that point to sedimentation only shortly before its subsequent history of high-grade metamorphism in the Middle to Late Permian (San Rafael orogeny) and exhumation during the Triassic. This suggests that the two terranes underwent different geological histories and were simply juxtaposed along the Atacama fault system.

\section{Sampling and analytical methods}

Samples of metasedimentary and igneous rocks were collected at locations throughout the Mejillones Peninsula, of which eight were selected for SHRIMP U-Pb zircon dating. Sample locations are shown in Fig. 1. Coordinates and abbreviated mineralogy of the analysed samples are shown in Table 1. Notably, two samples (MEJ-18029 and MEJ-18030) were collected near the sampling locality of Lucassen et al. (2000).

\subsection{Sample description}

\subsubsection{Metasedimentary rock samples}

MEJ-18025 is a banded gneiss interbedded with grey metapsammitic beds and discordantly intruded by apophyses of the Morro Mejillones pluton. The banding reflects alternation of thin biotite-rich and thicker quartz-rich layers. This foliation $\left(\mathrm{S}_{0}-\mathrm{S}_{1}\right)$ is folded: $\mathrm{F}_{2}$ folds are a few $\mathrm{cm}$ to several metres in amplitude and are accompanied by development of an axial planar foliation $\left(S_{2}\right)$ due to new growth of biotite and sillimanite. Mineral composition is quartz, biotite, plagioclase, K-feldspar, muscovite, sillimanite (fibrolite), andalusite and minor graphite, ore minerals and zircon. Andalusite is found as randomly orientated porphyroblasts, probably resulting from a late contact metamorphic overprint. Sillimanite and K-feldspar suggest that the rock reached high-grade metamorphic conditions during $\mathrm{F}_{2}$.

FO0928 is a mica schist in the northern block with a cm-spaced crenulation cleavage $S_{2}$, axial planar to open folds and numerous small folds in rootless quartz veins. The rocks are intruded by crosscutting decimetric tabular granitic bodies, probably apophyses of the nearby Morro Mejillones pluton. The rock contains oriented biotite and white mica as layers alternating with quartz richer bands.

MEJ-18030 is a banded biotite gneiss in the central block (Morro Jorgino) intercalated with amphibolite and leucogranite sheets. Its mineral composition is plagioclase, biotite and quartz with accessory zircon and apatite, and minor retrograde chlorite. The plagioclase texture is polygonal granoblastic, suggesting annealing of the rocks after deformation.

F00930 is a banded schist on the northeastern slope of Morro Jorgino, with frequent decimetric, rootless, isoclinal folds in quartz veins. The rock is well foliated and consists of quartz, plagioclase, biotite, and white mica, with ilmenite, zircon and apatite as accessory minerals.

F01139 is a banded schist in the central block consisting of coarse quartz bands and lenses separated by thinner biotite-rich layers, as in MEJ-18025. The biotite-rich layers contain abundant poikilitic plagioclase crystals, with unorientated biotite and quartz inclusions. Garnets are present as large equant porphyroblasts and as elongated crystals parallel to the banding of the rock, both with irregular margins. They contain quartz and opaque mineral inclusions. Opaque minerals including monazite are intergrown with biotite in some bands. The biotite has numerous zircon inclusions with dark haloes. White mica and chlorite are accessory.

\subsubsection{Igneous rock samples}

MEJ-18024 from Morro Mejillones is a coarse-grained tonalite with hornblende, biotite, plagioclase, K-feldspar $(<5 \%)$, quartz, and titanite, ore minerals, apatite, and zircon as accessories. Secondary minerals are chlorite, epidote and sericite. No evidence for subsolidus strain is recognized.

MEJ-18029, from the same locality as MEJ-18030 on Morro Jorgino, sampled a leucogranite body almost concordant with the foliation of the host banded gneiss (Fig. 3). The leucogranite contains scattered garnet, and a little biotite, the latter showing a preferred orientation roughly parallel to the contacts, i.e., a continuous foliation. The mineral composition is quartz, microcline, plagioclase, biotite and muscovite with garnet, zircon, monazite, apatite and ore minerals as accessories. Secondary minerals are chlorite, calcite, epidote, sericite and ore minerals. No textures indicative of significant subsolidus strain are recognized.

MEJ-18031 from near Cerro Moreno in the southern block is a mylonitic hornblende-biotite quartz-diorite of the Bólfin-Punta Tetas intrusive complex. The rock consists of hornblende, plagioclase, quartz, biotite and relict clinopyroxene with accessory zircon, apatite and epidote. A mylonitic foliation is well developed with porphyroclasts of plagioclase and hornblende wrapped in a foliated groundmass of recrystallized fine-grained biotite, hornblende, plagioclase and quartz.

\subsection{Analytical methods}

$\mathrm{U}-\mathrm{Pb}$ analyses were performed using SHRIMP RG at the Research School of Earth Sciences, The Australian National University, Canberra. Zircon fragments were mounted in epoxy together with chips of the Temora standard zircon, ground approximately half-way through and polished. Reflected and transmitted light photomicrographs, and cathodo-luminescence (CL) SEM images, were used to decipher the internal structures of the sectioned grains and to target specific areas within the zircons. The number of areas analysed per sample ranged from 25 to 60 and 20 to 30 in metasedimentary and igneous rocks respectively. The number of grains analysed for provenance was small in some metasedimentary samples. Reliable evidence was however

Table 1

Samples selected for U-Pb SHRIMP zircon dating.

\begin{tabular}{|c|c|c|c|}
\hline Block & Sample & Coordinates & Rock type \\
\hline Northern & MEJ-18024 & $23^{\circ} 05^{\prime} 46.1^{\prime \prime}-70^{\circ} 30^{\prime} 54.5^{\prime \prime}$ & Hornblende-biotite tonalite (Morro de Mejillones pluton) \\
\hline Northern & MEJ-18025 & $23^{\circ} 04^{\prime} 24.2^{\prime \prime}-70^{\circ} 31^{\prime} 11.1^{\prime \prime}$ & Banded sillimanite-andalusite-biotite gneiss \\
\hline Northern & FO0928 & $23^{\circ} 03^{\prime} 50.4^{\prime \prime}-70^{\circ} 32^{\prime} 31.2^{\prime \prime}$ & Biotite-schist \\
\hline Central & MEJ-18029 & $23^{\circ} 18^{\prime} 14.0^{\prime \prime}-70^{\circ} 34^{\prime} 28.9^{\prime \prime}$ & Garnet-bearing leucogranite \\
\hline Central & MEJ-18030 & $23^{\circ} 18^{\prime} 14.0^{\prime \prime}-70^{\circ} 34^{\prime} 28.9^{\prime \prime}$ & Banded biotite-gneiss \\
\hline Central & FO0930 & $23^{\circ} 14^{\prime} 07.2^{\prime \prime}-70^{\circ} 34^{\prime} 45.3^{\prime \prime}$ & Banded biotite-gneiss \\
\hline Central & F01139 & $23^{\circ} 15^{\prime} 35.2^{\prime \prime}-70^{\circ} 35^{\prime} 26.5^{\prime \prime}$ & Banded garnet-biotite gneiss \\
\hline Southern & MEJ-18031 & $23^{\circ} 29^{\prime} 33.6^{\prime \prime}-70^{\circ} 36^{\prime} 37.9^{\prime \prime}$ & Mylonitic quartz-diorite (Bólfín-Punta Tetas igneous complex) \\
\hline
\end{tabular}


obtained to constrain the age of the protoliths and that of metamorphic processes. The data were reduced in a manner similar to that described by Williams (1998, and references therein), using the SQUID Excel macro of Ludwig (2001). U-Pb data for the metasedimentary samples are given in Table 2 and for the igneous samples in Table 3. Partial probability plots of detrital zircon ages (showing ages back to $700 \mathrm{Ma}$ ) are shown in Fig. 4 and described below.

\section{Analytical results}

\subsection{Metasedimentary rocks}

The majority of zircons separated from MEJ-18025 are elongated grains with simple igneous concentric zonation, sometimes with high-U and developed on older cores, although a few are rounded grains with complex or "soccer-ball" zoning. Unmeasurably thin metamorphic rims exist on most grains. In reflected light all grains have pitted surfaces consistent with surface transport and hence a detrital origin. The SHRIMP analyses $(n=30)$ show mostly normal igneous $\mathrm{Th} / \mathrm{U}$ ratios of $0.25-1.5$. The $\mathrm{U}-\mathrm{Pb}$ ages range from ca. $210 \mathrm{Ma}$ to 1700 Ma. A peak at ca. 210 Ma is defined by analyses of three simple concentrically zoned igneous grains (U ca. 200-250, Th ca. 100 ppm). We see no reason to suspect that these either grew in situ at this time (in which case they would probably have much higher $U$ and lower Th contents) or that, given their consistency, they crystallized much earlier and were subject to Pb-loss at $210 \mathrm{Ma}$; they are therefore assumed to date the age of a provenance component. Other reasonably well-defined peaks occur at ca. 275, 340, 510, 545, 625, 1045 and $1650 \mathrm{Ma}$ (Fig. 4), suggesting that zircons were ultimately derived from a complex continental source. From the age of the youngest detrital zircons, the sedimentary protolith cannot have been older than Late Triassic (Norian).

F00928 has a zircon detrital pattern with a predominant Early to Middle Ordovician population between 465 and $495 \mathrm{Ma}$ (corresponding to the Famatinian orogeny) and a minor Cambrian peak at $515 \mathrm{Ma}$ (Fig. 4), as well as some Proterozoic ages (a significant number of grains in the range $800-1400 \mathrm{Ma}$, and single grain ages at 1.7, 1.9 and $2.6 \mathrm{Ga}$ ). One apparent age of 44 Ma was rejected due to an extremely high common $\mathrm{Pb}$ content, as were four other ages. Two Jurassic ages were discounted on the basis of geological evidence (see below). The youngest reliable ages in this sample are Carboniferous.

MEJ-18030 contains zircons with a wide variety of morphologies revealed by cathodo-luminescence imaging, with zoned or unzoned cores often overgrown by later zircon. One large euhedral grain gave an anomalous age of $58 \mathrm{Ma}$ and was discounted as a potential contaminant. The remaining 42 ages range between ca. $205 \mathrm{Ma}$ and $2700 \mathrm{Ma}$, with many apparent peaks, of which the best-defined are at ca. 255, 290-320, 355, 480, 610 and $1120 \mathrm{Ma}$ (Fig. 4). Most grains appear to be simple igneous zircons, but some show very thin metamorphic overgrowths (e.g., \# 16.1, with the youngest age at $205 \mathrm{Ma}$ and \# 6 at $500 \mathrm{Ma}$ ). The maximum age of sedimentation of the protolith is best assessed as ca. $255 \mathrm{Ma}$ (based on three grains). The detrital zircon pattern of this Morro Jorgino gneiss is essentially very similar to that of the Punta Angamos gneiss (MEJ-18025), except that the latter has a higher proportion of Mesoproterozoic grains at ca. 1.0-1.3 Ma and at 1.6-1.7 Ga.

F00930 has three grains that gave Cretaceous (\# 31.1) or Jurassic (\# 1.1 and 7.1) ages, two of which could be rejected for analytical reasons (high common $\mathrm{Pb}$ contents), although the geological situation suggests that they do not record primary crystallization (see below). The youngest reliable age seems to be ca. $220 \mathrm{Ma}$ (Table 2). The main part of the detrital zircon pattern is otherwise very similar to that of FO0928 in the northern block, with a predominant Early to Middle Ordovician population and a minor Cambrian peak (in this case ca. $550 \mathrm{Ma}$ ). The older components are mostly 800-1300 Ma, with one grain dated as $2.0 \mathrm{Ga}$.
F01139 contains a complex, heterogeneous population of zircons. They range from equant to elongate subhedral grains, a few with pyramidal terminations; most have mottled surfaces and overgrowths that can be seen under transmitted light. The $\mathrm{CL}$ images reveal the true complexity of the internal structure. The mottled rims range from thin dark oscillatory-zoned components to broader areas with a uniformly grey CL response. For the current study 25 areas were analysed on 15 zircon grains. In general those areas analysed as inherited cores yield older ${ }^{206} \mathrm{~Pb} /{ }^{238} \mathrm{U}$ ages, ranging back to $\sim 1170 \mathrm{Ma}$, but most are Palaeozoic to Triassic $(240,290,450,530 \mathrm{Ma})$ although the small number of analyses may not be fully representative. Many of the zoned rims are characterised by relatively high $\mathrm{U}$ (600-800, ranging up to $2235 \mathrm{ppm})$ and low Th with $\mathrm{Th} / \mathrm{U} \leq 0.06$ with some $\leq 0.02$ suggesting that they are metamorphic. There is also variable enrichment in common $\mathrm{Pb}$. The distribution of ${ }^{206} \mathrm{~Pb} /{ }^{238} \mathrm{U}$ ages shows scatter, but in general there is a grouping of these rim areas around 205-215 Ma and a lesser grouping at about 180-195 Ma (Fig. 4).

\subsection{Igneous rocks}

Zircons from MEJ-18024 $(\mathrm{n}=20$ ) are all igneous with high Th/U ratios between 0.37 and 0.88 . Their ${ }^{206} \mathrm{~Pb} /{ }^{238} \mathrm{U}$ ages range from 198 to $212 \mathrm{Ma}$, with an overall mean of $207 \mathrm{Ma}$ but a rather high MSWD of 2.2. In a probability plot there is a distinct skew to the younger ages, as might be expected if there were slight $\mathrm{Pb}$-loss effects. Ignoring the youngest three ages to allow for this (\# 13.1 has a high common P content), the weighted mean age of the remaining 17 grains is $208 \pm 2 \mathrm{Ma}$ $(\mathrm{MSWD}=1.4)$, which is taken to date a Late Triassic (Norian) crystallization age (Fig. 5).

The zircons from MEJ-18029 are clearly multi-stage, with grains exhibiting concentric igneous zonation, many of which have overgrowths with exceptionally high $U$ contents (up to $8676 \mathrm{ppm}$ ), some of which are metamict (Fig. 6). Crystallization of very high-U zircon in leucogranites is possibly a result of anatexis in an upper crustal environment. The ages $(n=30)$ spread from ca. 150 Ma to ca. 1450 Ma, but with a clear inverse relationship to $U$ content: all grains with $>1000 \mathrm{ppm}$ have ages $<211 \mathrm{Ma}$. The low-U grains have apparent age peaks at ca. $147 \mathrm{Ma}, 220-220 \mathrm{Ma}, 290$, and $485 \mathrm{Ma}$, as well as scattered single ages at 1000-1450 Ma (Fig. 5), which must represent inheritance from a sedimentary source. The single age of 147 Ma has been ignored as it requires an extremely high common $\mathrm{Pb}$ correction compared to the other data, so that the leucogranite must have acquired its inherited components during a melting event younger than $200 \mathrm{Ma}$. The ages of the high-U group range from $211 \mathrm{Ma}$ down to $164 \mathrm{Ma}$; six of these ages are consistent, yielding a weighted mean of $180 \pm 2 \mathrm{Ma}$ (MSWD $=1.3$ ). This would normally be interpreted as dating crystallization of the granite, but could not explain the fact that seven of the high-U overgrowths give older ages. Alternatively, since $\mathrm{Pb}-$ loss would have been facilitated by the radiation-damaged structure of metamict zircon (e.g., Mezger and Krogstad, 2004) it is possible that this resulted from a thermal overprint during emplacement of the nearby Jurassic batholith, and that the original age of the anatexis event that produced the leucogranite was ca. $210 \mathrm{Ma}$.

MEJ-18031 zircons are very large simple, prismatic and of igneous appearance. Ages $(\mathrm{n}=20)$ are very consistent: ignoring the one apparent outlier at $165 \mathrm{Ma}$, the weighted average age of 19 grains is $184 \pm 1$ Ma (MSWD = 1.04), i.e., Pliensbachian (Early Jurassic). This is taken as the age of magmatic crystallization (Fig. 5).

\section{Discussion}

\subsection{Summary of $U-P b$ SHRIMP results}

In the northern block the maximum possible sedimentary age of the protolith to sample MEJ-18025 (ca. $210 \mathrm{Ma}$ ) and the crystallization age of the Morro de Mejillones pluton hornblende-biotite 
Table 2

Summary of SHRIMP U-Pb zircon results for Mejillones metasedimentary samples.

\begin{tabular}{|c|c|c|c|c|c|c|c|c|c|c|c|c|c|c|c|c|c|c|c|c|c|c|}
\hline \multirow[b]{2}{*}{ Grain spot } & \multirow[b]{2}{*}{$\begin{array}{l}\mathrm{U} \\
(\mathrm{ppm})\end{array}$} & \multirow[b]{2}{*}{$\begin{array}{l}\text { Th } \\
\text { (ppm) }\end{array}$} & \multirow[b]{2}{*}{ Th/U } & \multirow[b]{2}{*}{$\begin{array}{c}{ }^{206} \mathrm{~Pb}^{\mathrm{a}} \\
(\mathrm{ppm})\end{array}$} & \multirow[b]{2}{*}{${ }^{204} \mathrm{~Pb} /{ }^{206} \mathrm{~Pb}$} & \multirow[b]{2}{*}{$\begin{array}{l}\mathrm{f}_{206} \\
\%\end{array}$} & \multicolumn{4}{|l|}{ Total ratios } & \multicolumn{6}{|c|}{ Radiogenic ratios } & & Age (Ma) & & & & \\
\hline & & & & & & & ${ }^{238} \mathrm{U} /{ }^{206} \mathrm{~Pb}$ & \pm & ${ }^{207} \mathrm{~Pb} /{ }^{206} \mathrm{~Pb}$ & \pm & ${ }^{206} \mathrm{~Pb} /{ }^{238} \mathrm{U}$ & \pm & ${ }^{207} \mathrm{~Pb} /{ }^{235} \mathrm{U}$ & \pm & ${ }^{207} \mathrm{~Pb} /{ }^{206} \mathrm{~Pb}$ & \pm & $\rho$ & ${ }^{206} \mathrm{~Pb} /{ }^{238} \mathrm{U}$ & \pm & ${ }^{207} \mathrm{~Pb} /{ }^{206} \mathrm{~Pb}$ & \pm & $\%$ disc \\
\hline MEJ-18025 b & anded $g n$ & eiss, north & ern blocl & & & & & & & & & & & & & & & & & & & \\
\hline 1.1 & 145 & 93 & 0.64 & 10 & 0.000295 & 0.01 & 11.924 & 0.161 & 0.0578 & 0.0010 & 0.0839 & 0.0012 & & & & & & 519 & 7 & & & \\
\hline 2.1 & 279 & 291 & 1.04 & 21 & 0.000159 & $<0.01$ & 11.382 & 0.136 & 0.0575 & 0.0010 & 0.0880 & 0.0011 & & & & & & 543 & 6 & & & \\
\hline 3.1 & 918 & 415 & 0.45 & 43 & 0.000030 & 0.03 & 18.525 & 0.199 & 0.0535 & 0.0005 & 0.0540 & 0.0006 & & & & & & 339 & 4 & & & \\
\hline${ }^{a} 4.1$ & 78 & 73 & 0.93 & 0 & 0.019185 & 22.01 & 294.9 & 12.6 & 0.2204 & 0.0555 & 0.0026 & 0.0003 & & & & & & 17 & 2 & & & \\
\hline 5.1 & 817 & 439 & 0.54 & 58 & 0.000077 & $<0.01$ & 12.156 & 0.130 & 0.0573 & 0.0004 & 0.0823 & 0.0009 & & & & & & 510 & 5 & & & \\
\hline 6.1 & 397 & 57 & 0.14 & 34 & 0.000061 & 0.06 & 9.950 & 0.117 & 0.0608 & 0.0006 & 0.1004 & 0.0012 & & & & & & 617 & 7 & & & \\
\hline 7.1 & 204 & 98 & 0.48 & 6 & 0.000303 & 0.34 & 29.884 & 0.451 & 0.0530 & 0.0013 & 0.0334 & 0.0005 & & & & & & 211 & 3 & & & \\
\hline 8.1 & 274 & 19 & 0.07 & 19 & 0.000135 & 0.05 & 12.088 & 0.144 & 0.0580 & 0.0007 & 0.0827 & 0.0010 & & & & & & 512 & 6 & & & \\
\hline${ }^{a} 9.1$ & 902 & 103 & 0.11 & 146 & 0.000065 & 0.11 & 5.308 & 0.057 & 0.1038 & 0.0006 & 0.1882 & 0.0020 & 2.670 & 0.033 & 0.1029 & 0.0006 & 0.881 & 1112 & 11 & 1677 & 11 & 34 \\
\hline 10.1 & 491 & 15 & 0.03 & 74 & 0.000002 & $<0.01$ & 5.688 & 0.065 & 0.0742 & 0.0027 & 0.1758 & 0.0020 & 1.798 & 0.068 & 0.0742 & 0.0027 & 0.300 & 1044 & 11 & 1047 & 73 & 0 \\
\hline 11.1 & 282 & 163 & 0.58 & 14 & - & $<0.01$ & 17.620 & 0.216 & 0.0533 & 0.0008 & 0.0568 & 0.0007 & & & & & & 356 & 4 & & & \\
\hline 12.1 & 371 & 108 & 0.29 & 52 & 0.000051 & 0.09 & 6.118 & 0.090 & 0.0724 & 0.0012 & 0.1633 & 0.0024 & 1.614 & 0.036 & 0.0717 & 0.0012 & 0.662 & 975 & 13 & 976 & 34 & 0 \\
\hline 13.1 & 198 & 73 & 0.37 & 15 & 0.000054 & 0.15 & 11.269 & 0.143 & 0.0597 & 0.0009 & 0.0886 & 0.0011 & & & & & & 547 & 7 & & & \\
\hline 14.1 & 453 & 293 & 0.65 & 30 & 0.000089 & $<0.01$ & 12.805 & 0.146 & 0.0561 & 0.0006 & 0.0782 & 0.0009 & & & & & & 485 & 5 & & & \\
\hline 15.1 & 253 & 92 & 0.36 & 7 & 0.000772 & 0.42 & 29.044 & 0.408 & 0.0538 & 0.0013 & 0.0343 & 0.0005 & & & & & & 217 & 3 & & & \\
\hline 16.1 & 203 & 186 & 0.92 & 19 & - & 0.69 & 9.199 & 0.117 & 0.0673 & 0.0008 & 0.1080 & 0.0014 & & & & & & 661 & 8 & & & \\
\hline 17.1 & 504 & 200 & 0.40 & 39 & - & $<0.01$ & 11.058 & 0.125 & 0.0583 & 0.0005 & 0.0905 & 0.0010 & & & & & & 558 & 6 & & & \\
\hline 18.1 & 542 & 844 & 1.56 & 47 & 0.000072 & 0.10 & 9.829 & 0.109 & 0.0614 & 0.0005 & 0.1016 & 0.0011 & & & & & & 624 & 7 & & & \\
\hline 19.1 & 215 & 110 & 0.51 & 9 & 0.000184 & 0.38 & 20.805 & 0.287 & 0.0554 & 0.0011 & 0.0479 & 0.0007 & & & & & & 302 & 4 & & & \\
\hline 20.1 & 426 & 159 & 0.37 & 16 & 0.001951 & 0.40 & 22.799 & 0.312 & 0.0550 & 0.0013 & 0.0437 & 0.0006 & & & & & & 276 & 4 & & & \\
\hline 21.1 & 222 & 127 & 0.57 & 6 & 0.000510 & 0.14 & 30.225 & 0.426 & 0.0514 & 0.0012 & 0.0330 & 0.0005 & & & & & & 210 & 3 & & & \\
\hline 22.1 & 193 & 37 & 0.19 & 29 & 0.000055 & 0.09 & 5.687 & 0.075 & 0.0726 & 0.0007 & 0.1758 & 0.0024 & 1.752 & 0.042 & 0.0723 & 0.0011 & 0.781 & 1044 & 13 & 994 & 32 & -5 \\
\hline 23.1 & 245 & 131 & 0.53 & 60 & 0.000027 & 0.04 & 3.519 & 0.042 & 0.1008 & 0.0022 & 0.2840 & 0.0034 & 3.935 & 0.100 & 0.1005 & 0.0023 & 0.466 & 1612 & 17 & 1633 & 42 & 1 \\
\hline 24.1 & 151 & 90 & 0.60 & 26 & 0.000109 & 0.18 & 5.021 & 0.066 & 0.0817 & 0.0008 & 0.1988 & 0.0026 & 2.198 & 0.047 & 0.0802 & 0.0013 & 0.618 & 1169 & 14 & 1202 & 33 & 3 \\
\hline 25.1 & 238 & 105 & 0.44 & 9 & 0.006758 & 1.95 & 22.439 & 0.385 & 0.0674 & 0.0021 & 0.0437 & 0.0008 & & & & & & 276 & 5 & & & \\
\hline 26.1 & 339 & 73 & 0.22 & 25 & 0.001181 & 1.44 & 11.427 & 0.141 & 0.0699 & 0.0008 & 0.0862 & 0.0011 & & & & & & 533 & 6 & & & \\
\hline a27.1 & 1311 & 186 & 0.14 & 74 & 0.003810 & 7.12 & 15.221 & 0.164 & 0.1117 & 0.0020 & 0.0610 & 0.0007 & & & & & & 382 & 4 & & & \\
\hline 28.1 & 180 & 68 & 0.38 & 8 & 0.000083 & $<0.01$ & 18.516 & 0.283 & 0.0524 & 0.0023 & 0.0541 & 0.0008 & & & & & & 339 & 5 & & & \\
\hline 29.1 & 792 & 154 & 0.19 & 185 & 0.000022 & 0.04 & 3.669 & 0.043 & 0.1039 & 0.0006 & 0.2724 & 0.0032 & 3.893 & 0.050 & 0.1036 & 0.0006 & 0.899 & 1553 & 16 & 1690 & 10 & 8 \\
\hline 30.1 & 854 & 237 & 0.28 & 55 & 0.000256 & 0.42 & 13.362 & 0.243 & 0.0597 & 0.0006 & 0.0745 & 0.0014 & & & & & & 463 & 8 & & & \\
\hline Error in Ten & ora refer & ence zircs & n calibr. & tion was & $0.62 \%$ for the & Inalytical & session. & & & & & & & & & & & & & & & \\
\hline FO0928 bioti & te schist, & northern & lock & & & & & & & & & & & & & & & & & & & \\
\hline 1.1 & 308 & 58 & 0.19 & 22 & 0.000051 & 0.15 & 11.947 & 0.136 & 0.0589 & 0.0007 & 0.0836 & 0.0010 & & & & & & 517 & 6 & & & \\
\hline 2.1 & 444 & 47 & 0.11 & 49 & - & $<0.01$ & 7.753 & 0.086 & 0.0697 & 0.0005 & 0.1290 & 0.0014 & 1.246 & 0.017 & 0.0700 & 0.0006 & 0.809 & 782 & 8 & 929 & 17 & 16 \\
\hline 3.1 & 117 & 51 & 0.44 & 17 & 0.000221 & 0.38 & 5.890 & 0.073 & 0.0762 & 0.0009 & 0.1691 & 0.0021 & 1.704 & 0.046 & 0.0731 & 0.0017 & 0.469 & 1007 & 12 & 1016 & 48 & 1 \\
\hline${ }^{2} 4.1$ & 42 & 0 & 0.00 & 3 & - & 6.84 & 10.722 & 0.180 & 0.1139 & 0.0386 & 0.0869 & 0.0047 & & & & & & 537 & 28 & & & \\
\hline${ }^{\mathrm{a}} 5.1$ & 285 & 90 & 0.31 & 3 & - & 45.43 & 79.097 & 1.192 & 0.4067 & 0.0061 & 0.0069 & 0.0002 & & & & & & 44 & 1 & & & \\
\hline${ }^{a} 6.1$ & 224 & 93 & 0.41 & 14 & 0.001232 & 7.16 & 13.475 & 0.241 & 0.1134 & 0.0278 & 0.0689 & 0.0029 & & & & & & 430 & 17 & & & \\
\hline 7.1 & 777 & 55 & 0.07 & 114 & 0.000095 & 0.16 & 5.847 & 0.062 & 0.0727 & 0.0003 & 0.1707 & 0.0018 & 1.681 & 0.022 & 0.0714 & 0.0005 & 0.830 & 1016 & 10 & 968 & 15 & -5 \\
\hline 8.1 & 116 & 93 & 0.80 & 7 & 0.000327 & 0.35 & 13.370 & 0.182 & 0.0591 & 0.0013 & 0.0745 & 0.0010 & & & & & & 463 & 6 & & & \\
\hline 9.1 & 382 & 94 & 0.25 & 25 & 0.000032 & 0.10 & 13.220 & 0.149 & 0.0572 & 0.0007 & 0.0756 & 0.0009 & & & & & & 470 & 5 & & & \\
\hline 10.1 & 280 & 41 & 0.15 & 18 & 0.000020 & 0.16 & 13.100 & 0.152 & 0.0578 & 0.0007 & 0.0762 & 0.0009 & & & & & & 473 & 5 & & & \\
\hline 11.1 & 153 & 27 & 0.18 & 29 & 0.000139 & 0.23 & 4.593 & 0.056 & 0.0842 & 0.0009 & 0.2172 & 0.0027 & 2.465 & 0.057 & 0.0823 & 0.0016 & 0.536 & 1267 & 14 & 1252 & 38 & -1 \\
\hline 12.1 & 233 & 103 & 0.44 & 14 & 0.000121 & 0.49 & 14.352 & 0.179 & 0.0595 & 0.0010 & 0.0693 & 0.0009 & & & & & & 432 & 5 & & & \\
\hline 13.1 & 599 & 61 & 0.10 & 43 & 0.000103 & 0.65 & 11.927 & 0.128 & 0.0629 & 0.0005 & 0.0833 & 0.0009 & & & & & & 516 & 5 & & & \\
\hline 14.1 & 339 & 203 & 0.60 & 16 & - & 0.27 & 17.804 & 0.208 & 0.0557 & 0.0008 & 0.0560 & 0.0007 & & & & & & 351 & 4 & & & \\
\hline 15.1 & 61 & 50 & 0.82 & 10 & 0.000415 & 0.70 & 5.317 & 0.075 & 0.0903 & 0.0013 & 0.1867 & 0.0027 & 2.174 & 0.093 & 0.0844 & 0.0034 & 0.338 & 1104 & 15 & 1302 & 78 & 15 \\
\hline 16.1 & 191 & 56 & 0.30 & 35 & 0.000087 & 0.14 & 4.673 & 0.056 & 0.0810 & 0.0007 & 0.2137 & 0.0025 & 2.350 & 0.038 & 0.0798 & 0.0009 & 0.735 & 1248 & 14 & 1191 & 22 & -5 \\
\hline 17.1 & 549 & 175 & 0.32 & 93 & 0.000157 & 0.26 & 5.090 & 0.055 & 0.0803 & 0.0004 & 0.1959 & 0.0021 & 2.109 & 0.028 & 0.0781 & 0.0006 & 0.801 & 1153 & 11 & 1149 & 16 & 0 \\
\hline 18.1 & 640 & 25 & 0.04 & 46 & - & 0.31 & 12.001 & 0.129 & 0.0601 & 0.0005 & 0.0831 & 0.0009 & & & & & & 514 & 5 & & & \\
\hline 19.1 & 65 & 31 & 0.47 & 4 & 0.000292 & 0.75 & 13.234 & 0.201 & 0.0624 & 0.0016 & 0.0750 & 0.0012 & & & & & & 466 & 7 & & & \\
\hline 20.1 & 91 & 34 & 0.38 & 36 & 0.000038 & 0.05 & 2.139 & 0.026 & 0.1767 & 0.0010 & 0.4673 & 0.0058 & 11.356 & 0.156 & 0.1762 & 0.0011 & 0.898 & 2472 & 25 & 2618 & 10 & 6 \\
\hline 21.1 & 226 & 103 & 0.46 & 48 & 0.000021 & 0.03 & 4.013 & 0.063 & 0.1042 & 0.0023 & 0.2491 & 0.0039 & 3.568 & 0.099 & 0.1039 & 0.0024 & 0.572 & 1434 & 20 & 1694 & 42 & 15 \\
\hline 22.1 & 61 & 25 & 0.41 & 9 & 0.000133 & 0.23 & 5.690 & 0.079 & 0.0796 & 0.0012 & 0.1753 & 0.0024 & 1.880 & 0.050 & 0.0777 & 0.0018 & 0.524 & 1042 & 13 & 1140 & 45 & 9 \\
\hline 23.1 & 646 & 297 & 0.46 & 38 & 0.000096 & 0.27 & 14.536 & 0.155 & 0.0576 & 0.0005 & 0.0686 & 0.0007 & & & & & & 428 & 4 & & & \\
\hline
\end{tabular}




\begin{tabular}{|c|c|c|c|c|c|c|c|c|c|c|c|c|c|c|c|c|c|c|c|c|c|c|}
\hline \multirow[b]{2}{*}{ Grain spot } & \multirow[b]{2}{*}{$\begin{array}{l}\mathrm{U} \\
(\mathrm{ppm})\end{array}$} & \multirow[b]{2}{*}{$\begin{array}{l}\text { Th } \\
\text { (ppm) }\end{array}$} & \multirow[b]{2}{*}{ Th/U } & \multirow[b]{2}{*}{$\begin{array}{c}{ }^{206} \mathrm{pb}^{\mathrm{a}} \\
(\mathrm{ppm})\end{array}$} & \multirow[b]{2}{*}{${ }^{204} \mathrm{~Pb} /{ }^{206} \mathrm{~Pb}$} & \multirow[b]{2}{*}{$\begin{array}{l}\mathrm{f}_{206} \\
\%\end{array}$} & \multicolumn{4}{|l|}{ Total ratios } & Radiogenic & atios & & & & & & Age (Ma) & & & & \\
\hline & & & & & & & ${ }^{238} \mathrm{U} /{ }^{206} \mathrm{~Pb}$ & \pm & ${ }^{207} \mathrm{~Pb} / 206 \mathrm{~Pb}$ & \pm & ${ }^{206} \mathrm{~Pb} /{ }^{238} \mathrm{U}$ & \pm & ${ }^{207} \mathrm{~Pb} /{ }^{235} \mathrm{U}$ & \pm & ${ }^{207} \mathrm{~Pb} /{ }^{206} \mathrm{~Pb}$ & \pm & $\rho$ & ${ }^{206} \mathrm{~Pb} /{ }^{238} \mathrm{U}$ & \pm & ${ }^{207} \mathrm{~Pb} /{ }^{206} \mathrm{~Pb}$ & \pm & $\%$ disc \\
\hline${ }^{\mathrm{a}} 24.1$ & 200 & 165 & 0.83 & 6 & 0.005953 & 9.65 & 28.706 & 0.384 & 0.1271 & 0.0077 & 0.0315 & 0.0005 & & & & & & 200 & 3 & & & \\
\hline 25.1 & 214 & 22 & 0.10 & 14 & 0.000476 & 0.34 & 13.338 & 0.157 & 0.0591 & 0.0009 & 0.0747 & 0.0009 & & & & & & 465 & 5 & & & \\
\hline 26.1 & 238 & 76 & 0.32 & 15 & 0.000108 & 0.04 & 13.320 & 0.155 & 0.0567 & 0.0008 & 0.0750 & 0.0009 & & & & & & 466 & 5 & & & \\
\hline 27.1 & 567 & 205 & 0.36 & 68 & - & $<0.01$ & 7.166 & 0.076 & 0.0703 & 0.0004 & 0.1396 & 0.0015 & 1.363 & 0.017 & 0.0708 & 0.0005 & 0.838 & 843 & 8 & 951 & 14 & 11 \\
\hline 28.1 & 137 & 13 & 0.09 & 9 & 0.000818 & 1.89 & 13.284 & 0.175 & 0.0715 & 0.0011 & 0.0739 & 0.0010 & & & & & & 459 & 6 & & & \\
\hline 29.1 & 456 & 247 & 0.54 & 28 & 0.000209 & 0.35 & 13.798 & 0.150 & 0.0587 & 0.0006 & 0.0722 & 0.0008 & & & & & & 450 & 5 & & & \\
\hline 30.1 & 217 & 2 & 0.01 & 29 & 0.000007 & 0.01 & 6.446 & 0.075 & 0.0742 & 0.0012 & 0.1551 & 0.0018 & 1.585 & 0.031 & 0.0741 & 0.0012 & 0.587 & 930 & 10 & 1044 & 32 & 11 \\
\hline 31.1 & 528 & 260 & 0.49 & 32 & 0.000049 & 0.19 & 14.226 & 0.155 & 0.0572 & 0.0006 & 0.0702 & 0.0008 & & & & & & 437 & 5 & & & \\
\hline 32.1 & 388 & 31 & 0.08 & 25 & 0.000001 & 0.07 & 13.191 & 0.150 & 0.0570 & 0.0006 & 0.0758 & 0.0009 & & & & & & 471 & 5 & & & \\
\hline 33.1 & 189 & 112 & 0.59 & 13 & 0.000131 & $<0.01$ & 12.802 & 0.154 & 0.0564 & 0.0009 & 0.0782 & 0.0010 & & & & & & 485 & 6 & & & \\
\hline a 34.1 & 86 & 16 & 0.19 & 12 & 0.002652 & 4.55 & 6.075 & 0.179 & 0.0977 & 0.0105 & 0.1571 & 0.0048 & 1.282 & 0.284 & 0.0592 & 0.0130 & 0.138 & 941 & 27 & 574 & 478 & -64 \\
\hline 35.1 & 459 & 183 & 0.40 & 21 & 0.000186 & $<0.01$ & 18.544 & 0.205 & 0.0532 & 0.0006 & 0.0539 & 0.0006 & & & & & & 339 & 4 & & & \\
\hline 36.1 & 255 & 162 & 0.63 & 16 & 0.000051 & 0.02 & 13.871 & 0.173 & 0.0561 & 0.0009 & 0.0721 & 0.0009 & & & & & & 449 & 5 & & & \\
\hline 37.1 & 138 & 72 & 0.53 & 20 & 0.000014 & 0.02 & 5.875 & 0.072 & 0.0743 & 0.0008 & 0.1702 & 0.0021 & 1.738 & 0.029 & 0.0741 & 0.0008 & 0.730 & 1013 & 11 & 1043 & 23 & 3 \\
\hline a 38.1 & 204 & 124 & 0.61 & 5 & - & 0.32 & 32.375 & 0.430 & 0.0526 & 0.0014 & 0.0308 & 0.0004 & & & & & & 195 & 3 & & & \\
\hline 39.1 & 768 & 496 & 0.65 & 49 & 0.000058 & 0.12 & 13.346 & 0.144 & 0.0573 & 0.0004 & 0.0748 & 0.0008 & & & & & & 465 & 5 & & & \\
\hline 40.1 & 362 & 13 & 0.04 & 25 & 0.000007 & 0.55 & 12.538 & 0.142 & 0.0615 & 0.0007 & 0.0793 & 0.0009 & & & & & & 492 & 5 & & & \\
\hline 41.1 & 359 & 66 & 0.18 & 24 & 0.000187 & 0.04 & 12.860 & 0.146 & 0.0571 & 0.0007 & 0.0777 & 0.0009 & & & & & & 483 & 5 & & & \\
\hline 42.1 & 434 & 103 & 0.24 & 67 & 0.000033 & 0.06 & 5.571 & 0.063 & 0.0796 & 0.0005 & 0.1794 & 0.0020 & 1.959 & 0.026 & 0.0792 & 0.0006 & 0.840 & 1064 & 11 & 1177 & 14 & 10 \\
\hline 43.1 & 347 & 121 & 0.35 & 62 & 0.000010 & 0.02 & 4.824 & 0.053 & 0.0814 & 0.0005 & 0.2072 & 0.0023 & 2.321 & 0.030 & 0.0812 & 0.0005 & 0.864 & 1214 & 12 & 1227 & 13 & 1 \\
\hline 44.1 & 106 & 59 & 0.56 & 18 & 0.000068 & 0.11 & 5.108 & 0.066 & 0.0805 & 0.0009 & 0.1955 & 0.0025 & 2.144 & 0.045 & 0.0795 & 0.0013 & 0.612 & 1151 & 14 & 1185 & 33 & 3 \\
\hline 45.1 & 128 & 72 & 0.56 & 9 & 0.000475 & 0.23 & 11.913 & 0.158 & 0.0596 & 0.0012 & 0.0838 & 0.0011 & & & & & & 518 & 7 & & & \\
\hline 46.1 & 702 & 12 & 0.02 & 48 & 0.000001 & 0.09 & 12.541 & 0.135 & 0.0578 & 0.0005 & 0.0797 & 0.0009 & & & & & & 494 & 5 & & & \\
\hline 47.1 & 111 & 68 & 0.62 & 23 & - & $<0.01$ & 4.201 & 0.055 & 0.0891 & 0.0009 & 0.2382 & 0.0031 & 2.946 & 0.053 & 0.0897 & 0.0011 & 0.729 & 1377 & 16 & 1419 & 23 & 3 \\
\hline 48.1 & 397 & 120 & 0.30 & 77 & 0.000052 & 0.09 & 4.457 & 0.049 & 0.0874 & 0.0005 & 0.2242 & 0.0024 & 2.680 & 0.034 & 0.0867 & 0.0006 & 0.851 & 1304 & 13 & 1354 & 13 & 4 \\
\hline${ }^{a} 49.1$ & 148 & 164 & 1.11 & 3 & - & $<0.01$ & 38.918 & 0.600 & 0.0478 & 0.0031 & 0.0257 & 0.0004 & & & & & & 164 & 3 & & & \\
\hline 50.1 & 548 & 92 & 0.17 & 37 & 0.000019 & 0.18 & 12.577 & 0.139 & 0.0585 & 0.0006 & 0.0794 & 0.0009 & & & & & & 492 & 5 & & & \\
\hline 51.1 & 75 & 68 & 0.91 & 20 & - & $<0.01$ & 3.160 & 0.044 & 0.1142 & 0.0011 & 0.3166 & 0.0044 & 4.994 & 0.085 & 0.1144 & 0.0011 & 0.814 & 1773 & 22 & 1871 & 18 & 5 \\
\hline 52.1 & 247 & 60 & 0.24 & 17 & 0.000097 & 0.09 & 12.386 & 0.152 & 0.0580 & 0.0009 & 0.0807 & 0.0010 & & & & & & 500 & 6 & & & \\
\hline 53.1 & 310 & 12 & 0.04 & 25 & - & 0.58 & 10.752 & 0.127 & 0.0638 & 0.0008 & 0.0925 & 0.0011 & & & & & & 570 & 7 & & & \\
\hline 54.1 & 178 & 150 & 0.84 & 11 & 0.000060 & 0.34 & 13.923 & 0.175 & 0.0586 & 0.0010 & 0.0716 & 0.0009 & & & & & & 446 & 6 & & & \\
\hline 55.1 & 62 & 12 & 0.19 & 6 & 0.000243 & 0.61 & 8.516 & 0.131 & 0.0681 & 0.0017 & 0.1167 & 0.0019 & & & & & & 712 & 11 & & & \\
\hline 56.1 & 184 & 84 & 0.46 & 33 & 0.000002 & $<0.01$ & 4.787 & 0.057 & 0.0810 & 0.0007 & 0.2089 & 0.0025 & 2.331 & 0.034 & 0.0809 & 0.0007 & 0.805 & 1223 & 13 & 1220 & 17 & 0 \\
\hline 57.1 & 506 & 126 & 0.25 & 97 & 0.000005 & 0.01 & 4.462 & 0.048 & 0.0969 & 0.0008 & 0.2241 & 0.0024 & 2.993 & 0.040 & 0.0969 & 0.0008 & 0.809 & 1304 & 13 & 1565 & 15 & 17 \\
\hline 58.1 & 524 & 160 & 0.31 & 95 & 0.000040 & 0.07 & 4.743 & 0.051 & 0.0822 & 0.0007 & 0.2107 & 0.0023 & 2.372 & 0.034 & 0.0817 & 0.0008 & 0.761 & 1233 & 12 & 1237 & 18 & 0 \\
\hline 59.1 & 342 & 205 & 0.60 & 22 & 0.000250 & $<0.01$ & 13.510 & 0.162 & 0.0562 & 0.0007 & 0.0740 & 0.0009 & & & & & & 460 & 5 & & & \\
\hline 60.1 & 825 & 77 & 0.09 & 57 & 0.000005 & 0.30 & 12.427 & 0.131 & 0.0596 & 0.0004 & 0.0802 & 0.0009 & & & & & & 497 & 5 & & & \\
\hline Error in Ten & ora refer & ence zircs & n calibr & tion was & $0.94 \%$ for the & nalytical & ession. & & & & & & & & & & & & & & & \\
\hline MEJ-18030 & anded gn & iss, centr & l block & & & & & & & & & & & & & & & & & & & \\
\hline 1.1 & 278 & 226 & 0.82 & 11 & 0.000110 & 0.10 & 21.430 & 0.258 & 0.0530 & 0.0008 & 0.0466 & 0.0006 & & & & & & 294 & 3 & & & \\
\hline 2.1 & 264 & 102 & 0.39 & 32 & 0.000029 & 0.05 & 7.179 & 0.082 & 0.0669 & 0.0005 & 0.1392 & 0.0016 & 1.275 & 0.018 & 0.0664 & 0.0005 & 0.818 & 840 & 9 & 820 & 17 & -2 \\
\hline 3.1 & 382 & 645 & 1.69 & 32 & 0.000057 & $<0.01$ & 10.191 & 0.110 & 0.0592 & 0.0004 & 0.0982 & 0.0011 & & & & & & 604 & 6 & & & \\
\hline 4.1 & 110 & 48 & 0.44 & 19 & - & $<0.01$ & 5.068 & 0.061 & 0.0767 & 0.0007 & 0.1973 & 0.0024 & 2.087 & 0.031 & 0.0767 & 0.0007 & 0.807 & 1161 & 13 & 1114 & 18 & -4 \\
\hline 5.1 & 262 & 27 & 0.10 & 18 & 0.000081 & -0.10 & $\begin{array}{r}12.783 \\
\end{array}$ & 0.147 & 0.0560 & 0.0006 & 0.0783 & 0.0009 & & & & & & 486 & 5 & & & \\
\hline 6.1 & 334 & 53 & 0.16 & 23 & - & $<0.01$ & 12.319 & 0.156 & 0.0593 & 0.0005 & 0.0810 & 0.0010 & & & & & & 502 & 6 & & & \\
\hline 7.1 & 286 & 386 & 1.35 & 12 & 0.000179 & $<0.01$ & 20.979 & 0.244 & 0.0522 & 0.0007 & 0.0477 & 0.0006 & & & & & & 300 & 3 & & & \\
\hline 8.1 & 285 & 161 & 0.57 & 12 & 0.000139 & 0.43 & 20.701 & 0.241 & 0.0558 & 0.0008 & 0.0481 & 0.0006 & & & & & & 303 & 3 & & & \\
\hline 9.1 & 640 & 543 & 0.85 & 108 & 0.000008 & 0.01 & 5.088 & 0.055 & 0.0804 & 0.0004 & 0.1965 & 0.0021 & 2.174 & 0.025 & 0.0802 & 0.0004 & 0.922 & 1157 & 11 & 1203 & 9 & 4 \\
\hline 10.1 & 275 & 268 & 0.98 & 11 & - & $<0.01$ & 22.310 & 0.274 & 0.0516 & 0.0009 & 0.0448 & 0.0006 & & & & & & 283 & 3 & & & \\
\hline 11.1 & 461 & 28 & 0.06 & 31 & 0.000020 & 0.04 & 12.825 & 0.143 & 0.0572 & 0.0006 & 0.0779 & 0.0009 & & & & & & 484 & 5 & & & \\
\hline 12.1 & 577 & 59 & 0.10 & 38 & 0.000057 & $<0.01$ & 12.938 & 0.142 & 0.0566 & 0.0005 & 0.0773 & 0.0009 & & & & & & 480 & 5 & & & \\
\hline 13.1 & 345 & 198 & 0.57 & 17 & 0.000055 & $<0.01$ & 17.815 & 0.211 & 0.0520 & 0.0008 & 0.0562 & 0.0007 & & & & & & 353 & 4 & & & \\
\hline 14.1 & 649 & 48 & 0.07 & 43 & 0.000020 & $<0.01$ & 13.105 & 0.143 & 0.0563 & 0.0005 & 0.0763 & 0.0008 & & & & & & 474 & 5 & & & \\
\hline${ }^{\mathrm{a}} 15.1$ & 235 & 144 & 0.61 & 2 & 0.000368 & 0.38 & 110.48 & 1.93 & 0.0502 & 0.0022 & 0.0090 & 0.0002 & & & & & & 58 & 1 & & & \\
\hline 16.1 & 45 & 1 & 0.01 & 1 & - & 2.24 & 30.328 & 0.775 & 0.0681 & 0.0038 & 0.0322 & 0.0008 & & & & & & 205 & 5 & & & \\
\hline 16.2 & 495 & 512 & 1.03 & 33 & - & $<0.01$ & 13.062 & 0.146 & 0.0561 & 0.0006 & 0.0766 & 0.0009 & & & & & & 476 & 5 & & & \\
\hline 17.1 & 585 & 302 & 0.52 & 20 & 0.000101 & 0.04 & 24.805 & 0.284 & 0.0517 & 0.0007 & 0.0403 & 0.0005 & & & & & & 255 & 3 & & & \\
\hline 18.1 & 272 & 38 & 0.14 & 49 & 0.000021 & 0.04 & 4.798 & 0.056 & 0.0869 & 0.0006 & 0.2084 & 0.0024 & 2.489 & 0.034 & 0.0866 & 0.0006 & 0.851 & 1220 & 13 & 1352 & 14 & 10 \\
\hline
\end{tabular}




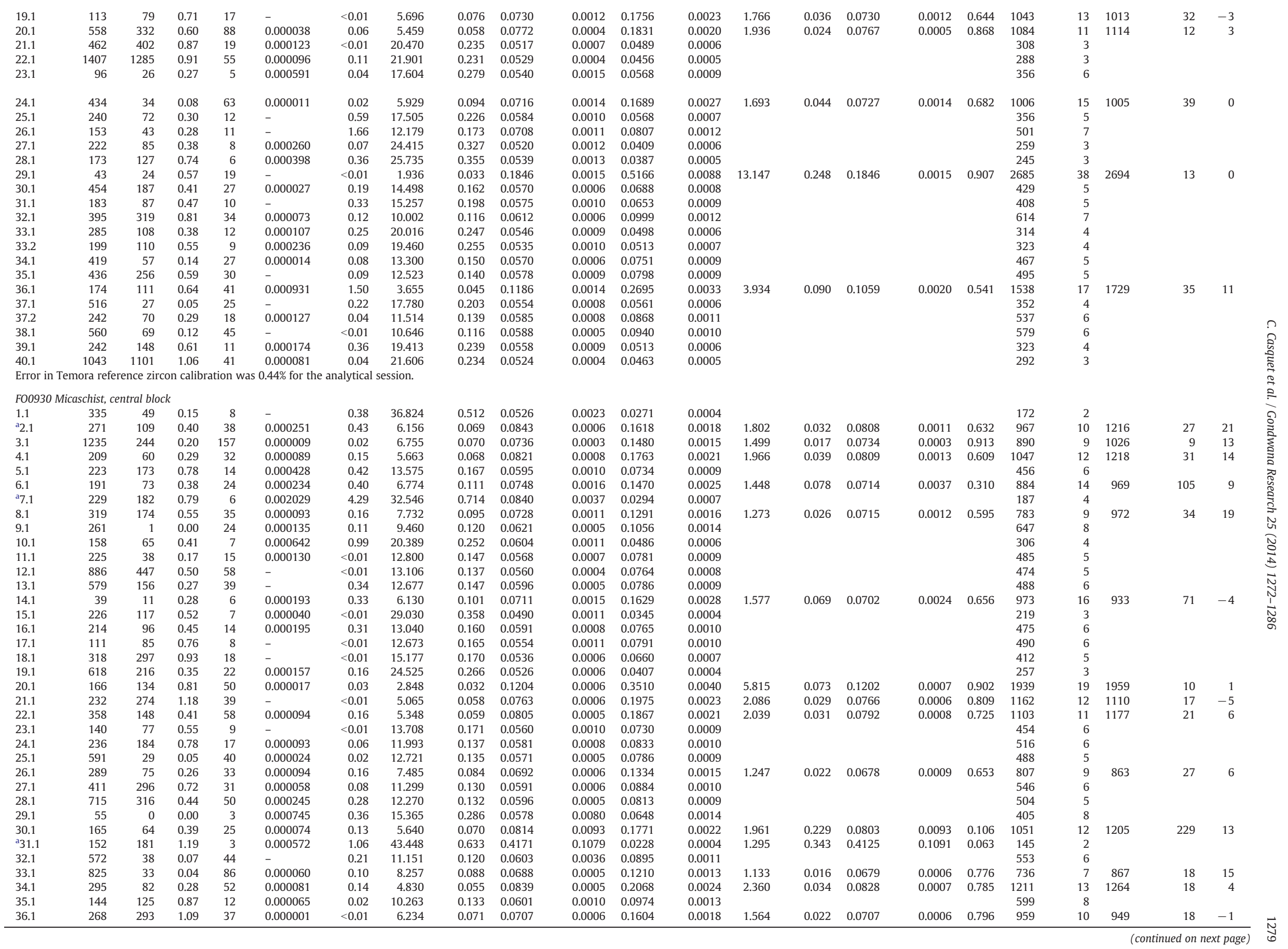


Table 2 (continued)

\begin{tabular}{|c|c|c|c|c|c|c|c|c|c|c|c|c|c|c|c|c|c|c|c|c|c|c|}
\hline \multirow[b]{2}{*}{ Grain spot } & \multirow[b]{2}{*}{$\begin{array}{l}\mathrm{U} \\
\text { (ppm) }\end{array}$} & \multirow[b]{2}{*}{$\begin{array}{l}\text { Th } \\
\text { (ppm) }\end{array}$} & \multirow[b]{2}{*}{ Th/U } & \multirow[b]{2}{*}{$\begin{array}{c}{ }^{206} \mathrm{~Pb}^{\mathrm{a}} \\
(\mathrm{ppm})\end{array}$} & \multirow[b]{2}{*}{${ }^{204} \mathrm{~Pb} /{ }^{206} \mathrm{~Pb}$} & \multirow[b]{2}{*}{$\begin{array}{l}\mathrm{f}_{206} \\
\%\end{array}$} & \multicolumn{4}{|l|}{ Total ratios } & \multicolumn{6}{|c|}{ Radiogenic ratios } & \multirow[b]{2}{*}{$\rho$} & \multicolumn{5}{|l|}{ Age (Ma) } \\
\hline & & & & & & & ${ }^{238} \mathrm{U} /{ }^{206} \mathrm{~Pb}$ & \pm & ${ }^{207} \mathrm{~Pb} /{ }^{206} \mathrm{~Pb}$ & \pm & ${ }^{206} \mathrm{~Pb} /{ }^{238} \mathrm{U}$ & \pm & ${ }^{207} \mathrm{~Pb} /{ }^{235} \mathrm{U}$ & \pm & ${ }^{207} \mathrm{~Pb} /{ }^{206} \mathrm{~Pb}$ & \pm & & ${ }^{206} \mathrm{~Pb} /{ }^{238} \mathrm{U}$ & \pm & ${ }^{207} \mathrm{~Pb} /{ }^{206} \mathrm{~Pb}$ & \pm & $\%$ disc \\
\hline 37.1 & 207 & 86 & 0.42 & 32 & - & $<0.01$ & 5.640 & 0.066 & 0.0740 & 0.0007 & 0.1773 & 0.0021 & 1.813 & 0.028 & 0.0742 & 0.0007 & 0.777 & 1052 & 11 & 1046 & 19 & -1 \\
\hline 38.1 & 658 & 208 & 0.32 & 76 & - & $<0.01$ & 7.415 & 0.080 & 0.0660 & 0.0004 & 0.1349 & 0.0015 & 1.232 & 0.016 & 0.0662 & 0.0005 & 0.839 & 816 & 8 & 814 & 15 & 0 \\
\hline 39.1 & 923 & 279 & 0.30 & 117 & 0.000037 & 0.06 & 6.790 & 0.072 & 0.0676 & 0.0003 & 0.1472 & 0.0016 & 1.361 & 0.017 & 0.0671 & 0.0004 & 0.876 & 885 & 9 & 840 & 12 & -5 \\
\hline 40.1 & 307 & 140 & 0.46 & 20 & 0.000164 & 0.25 & 13.222 & 0.151 & 0.0585 & 0.0007 & 0.0754 & 0.0009 & & & & & & 469 & 5 & & & \\
\hline \multicolumn{23}{|c|}{ Error in Temora reference zircon calibration was $0.94 \% \& 0.67 \%$ for the analytical sessions. } \\
\hline \multicolumn{23}{|c|}{ F01139 Mica schist, central block } \\
\hline 1.1 & 117 & 90 & 0.77 & 9 & 0.000420 & 0.37 & 11.658 & 0.172 & 0.0610 & 0.0012 & 0.0855 & 0.0013 & & & & & & 529 & 8 & & & \\
\hline 1.2 & 1239 & 98 & 0.08 & 33 & 0.003872 & 6.37 & 31.833 & 0.389 & 0.1007 & 0.0032 & 0.0294 & 0.0004 & & & & & & 187 & 2 & & & \\
\hline 2.1 & 328 & 5 & 0.02 & 10 & 0.000972 & 2.41 & 28.599 & 0.367 & 0.0697 & 0.0012 & 0.0341 & 0.0004 & & & & & & 216 & 3 & & & \\
\hline 2.2 & 1367 & 482 & 0.35 & 54 & 0.000132 & 0.17 & 21.881 & 0.252 & 0.0534 & 0.0005 & 0.0456 & 0.0005 & & & & & & 288 & 3 & & & \\
\hline 2.3 & 771 & 968 & 1.26 & 30 & 0.000076 & 0.13 & 21.968 & 0.267 & 0.0530 & 0.0006 & 0.0455 & 0.0006 & & & & & & 287 & 3 & & & \\
\hline 3.1 & 928 & 11 & 0.01 & 26 & 0.000371 & 0.35 & 30.448 & 0.379 & 0.0531 & 0.0008 & 0.0327 & 0.0004 & & & & & & 208 & 3 & & & \\
\hline 3.2 & 215 & 215 & 1.00 & 10 & 0.000405 & 0.29 & 19.365 & 0.253 & 0.0552 & 0.0010 & 0.0515 & 0.0007 & & & & & & 324 & 4 & & & \\
\hline 4.1 & 848 & 50 & 0.06 & 22 & 0.001784 & 3.90 & 33.888 & 0.425 & 0.0808 & 0.0011 & 0.0284 & 0.0004 & & & & & & 180 & 2 & & & \\
\hline 4.2 & 536 & 32 & 0.06 & 34 & 0.000636 & 1.18 & 13.744 & 0.164 & 0.0654 & 0.0008 & 0.0719 & 0.0009 & & & & & & 448 & 5 & & & \\
\hline 5.1 & 1176 & 14 & 0.01 & 31 & 0.000237 & 0.63 & 33.131 & 0.391 & 0.0549 & 0.0008 & 0.0300 & 0.0004 & & & & & & 191 & 2 & & & \\
\hline 5.2 & 62 & 46 & 0.74 & 4 & 0.000382 & 1.43 & 12.824 & 0.206 & 0.0682 & 0.0019 & 0.0769 & 0.0013 & & & & & & 477 & 8 & & & \\
\hline 6.1 & 934 & 27 & 0.03 & 29 & 0.000317 & 0.87 & 27.945 & 0.328 & 0.0576 & 0.0006 & 0.0355 & 0.0004 & & & & & & 225 & 3 & & & \\
\hline 6.2 & 257 & 78 & 0.30 & 44 & 0.000067 & 0.20 & 5.013 & 0.061 & 0.0806 & 0.0006 & 0.1991 & 0.0025 & & & & & & 1170 & 14 & & & \\
\hline 7.1 & 643 & 30 & 0.05 & 17 & 0.002218 & 4.30 & 33.180 & 0.413 & 0.0841 & 0.0035 & 0.0288 & 0.0004 & & & & & & 183 & 2 & & & \\
\hline 7.2 & 281 & 185 & 0.66 & 12 & 0.000440 & 0.44 & 20.727 & 0.265 & 0.0559 & 0.0009 & 0.0480 & 0.0006 & & & & & & 302 & 4 & & & \\
\hline 8.1 & 896 & 7 & 0.01 & 26 & 0.000234 & 0.39 & 29.486 & 0.354 & 0.0536 & 0.0006 & 0.0338 & 0.0004 & & & & & & 214 & 3 & & & \\
\hline 8.2 & 2234 & 26 & 0.01 & 62 & 0.000107 & 0.20 & 30.828 & 0.352 & 0.0518 & 0.0004 & 0.0324 & 0.0004 & & & & & & 205 & 2 & & & \\
\hline 8.3 & 452 & 282 & 0.63 & 27 & 0.000066 & 0.08 & 14.391 & 0.171 & 0.0562 & 0.0006 & 0.0694 & 0.0008 & & & & & & 433 & 5 & & & \\
\hline 9.1 & 1228 & 60 & 0.05 & 37 & 0.001382 & 2.77 & 28.830 & 0.379 & 0.0726 & 0.0013 & 0.0337 & 0.0004 & & & & & & 214 & 3 & & & \\
\hline 10.1 & 498 & 251 & 0.50 & 37 & 0.000060 & 0.06 & 11.653 & 0.138 & 0.0585 & 0.0005 & 0.0858 & 0.0010 & & & & & & 530 & 6 & & & \\
\hline 11.1 & 887 & 20 & 0.02 & 24 & 0.000085 & 0.48 & 32.205 & 0.382 & 0.0539 & 0.0008 & 0.0309 & 0.0004 & & & & & & 196 & 2 & & & \\
\hline 12.1 & 1828 & 20 & 0.01 & 52 & 0.000389 & 0.65 & 30.192 & 0.356 & 0.0555 & 0.0005 & 0.0329 & 0.0004 & & & & & & 209 & 2 & & & \\
\hline 13.1 & 38 & 1 & 0.03 & 1 & 0.005858 & 4.51 & 28.623 & 0.690 & 0.0864 & 0.0043 & 0.0334 & 0.0008 & & & & & & 212 & 5 & & & \\
\hline 14.1 & 66 & 0 & 0.00 & 2 & 0.001771 & 2.33 & 25.716 & 0.518 & 0.0697 & 0.0031 & 0.0380 & 0.0008 & & & & & & 240 & 5 & & & \\
\hline 15.1 & 607 & 188 & 0.31 & 23 & 0.002228 & 3.87 & 22.584 & 0.280 & 0.0827 & 0.0023 & 0.0426 & 0.0005 & & & & & & 269 & 3 & & & \\
\hline Error in Ten & ora refer & ric & & & $0.33 \%$ for the & nalytical & ccion & & & & & & & & & & & & & & & \\
\hline
\end{tabular}

Uncertainties given at the1 $\sigma$ level.

$\mathrm{f}_{206} \%$ denotes the percentage of ${ }^{206} \mathrm{~Pb}$ that is common $\mathrm{Pb}$.

$\mathrm{Pb}$ was made using the measured ${ }^{204} \mathrm{~Pb} /{ }^{206} \mathrm{~Pb}$ ratio.

For areas younger than $\sim 800 \mathrm{Ma}$ correction for common $\mathrm{Pb}$ was made using the measured ${ }^{238} \mathrm{U} /{ }^{206} \mathrm{~Pb}$ and ${ }^{207} \mathrm{~Pb} /{ }^{206} \mathrm{~Pb}$ ratios following Tera and Wasserburg (1972) as outlined in Williams (1998).

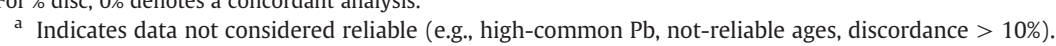


tonalite $(208 \pm 2 \mathrm{Ma})$ are coincident within analytical error. Since the intrusive contacts are discordant to both foliation and folding in the gneiss, and the tonalite itself does not show deformation, it is suggested that the sediment was deposited, buried, deformed and metamorphosed very shortly before magmatism at ca. $210 \mathrm{Ma}$, i.e., Late Triassic (Norian). In the central block, field evidence and the crystallization age of the garnet-bearing anatectic leucogranite (ca. $210 \mathrm{Ma}$ ) suggest that its intrusion was late but essentially coeval with the development of foliation in the host rocks. Metamorphic zircon overgrowth with an age of $205 \pm 5$ Ma in the gneiss MEJ-18030 reinforces the interpretation drawn from the northern block, suggesting that the first metamorphic event recorded here also took place at ca. $210 \mathrm{Ma}$. The same conclusion is reached from sample F01139, which shows metamorphic rim ages between 205 and 215 Ma (Fig. 4).

The maximum sedimentation age of the central block gneiss (MEJ-18030) can be constrained between ca. 205 and $255 \mathrm{Ma}$, but inherited zircons of $210-220 \mathrm{Ma}$ in the leucogranite suggest that maximum sedimentary ages in this block could also be as young as $210 \mathrm{Ma}$, similar to those in the northern block. Samples FO0928 and F009230 contain a few zircons with Jurassic ages. However these rocks show foliations and folds similar to those of the other metasedimentary rocks dealt with here; in consequence those ages are considered to be meaningless.

From the above it becomes clear that metasedimentary rocks that crop out in the northern and central blocks of the Mejillones peninsula are as young as Late Triassic and not Early Paleozoic as suggested by previous geochronological work.

\subsection{Comparison with published ages}

The $530 \mathrm{Ma} \mathrm{Rb}-\mathrm{Sr}$ reference isochron of Diaz et al. (1985) for the andalusite-zone schist at Punta Angamos in the northern sector $\left(23^{\circ} 10^{\prime} \mathrm{S} ; 70^{\circ} 34^{\prime} \mathrm{W}\right)$, based on only 3 out of 6 whole-rock samples, clearly cannot be regarded as significant, nor can other indications of 320 and $255 \mathrm{Ma}$, due to the low number of analyses and the absence of true isochrons. However, their Rb-Sr WR data for schists from the southern area were shown to fall on a reasonable errorchron given as $200 \pm 10 \mathrm{Ma}$ - our recalculation using Isoplot/Ex and with assumed analytical uncertainties results in an isochron (MSWD of 1.2 for 6 out of 8 analyses) with an age of $206 \pm 7 \mathrm{Ma}$, and an initial ${ }^{87} \mathrm{Sr} /{ }^{86} \mathrm{Sr}$ ratio of $0.7037 \pm 0.0002$. This is consistent with our conclusions for Late Triassic metamorphism in the northern and central blocks.

With regard to the Sm-Nd WR age of $521 \pm 55$ Ma for orthoamphibolite from the central outcrop obtained by Damm et al. (1990), we note that the large uncertainty on this age is highly dependant on the assumed analytical precision - a less optimistic estimate would result in a much higher age uncertainty. Support for Paleozoic crystallization was apparently given by these authors' U-Pb zircon discordia age for the Morro Mejillones pluton tonalite of $561+12 /-14$ Ma (upper intercept); the $175 \pm 10 \mathrm{Ma}$ lower intercept was interpreted as a cooling age. However the published data do not justify construction of a discordia line within assumed uncertainties - our recalculation of these intercepts gives rather meaningless ages of $717 \pm 330$ and $182 \pm 34$ Ma with MSWD $=37$. We believe that the lower intercept was interpreted more correctly as reflecting the crystallization age by Cortés et al. (2007).

Lucassen et al. (2000) obtained an age of $525 \pm 10$ Ma from a Sm-Nd mineral isochron from a Morro Jorgino garnet amphibolite. However, in this case the whole-rock analysis does not plot anywhere near the isochron, and the uncertainty reported corresponds to an unusually high estimated precision in the measured $\mathrm{Nd}$ isotope ratios (ca. $\pm 0.0005 \%$ ). Our samples MEJ-18029 and 18030 were collected essentially at the same location and fail to show any evidence for a Cambrian metamorphic age.

\subsection{Processes at the Late Triassic pre-Andean margin}

SHRIMP evidence from the northern block further suggests that sedimentary protoliths were buried, deformed (foliations and folding) and metamorphosed very rapidly, probably within a very few million years, at ca. $210 \mathrm{Ma}$. Moreover, the metasedimentary wedge was uplifted and intruded by late arc-related tonalite (Morro Mejillones) within a short time of the peak of metamorphism. The intrusion produced a contact metamorphic aureole (visible in the northern block only) with development of post- $S_{2}$ andalusite. The same early tectonometamorphic process also affected the rocks of the central block where a regional Barroviantype metamorphic zoning (Grt-Ky-Sill) is best displayed (Baeza, 1984). Annealing textures common in this block probably arose from a lowpressure thermal overprint resulting either from a hidden intrusion equivalent to the Morro de Mejillones pluton or from a regional heating event during the emplacement of the Jurassic Bólfin-Punta Tetas arc.

Evidence for igneous activity along the Andean margin at ca. $210 \mathrm{Ma}$ is also provided by the scarce detrital igneous zircons of this age in gneiss MEJ-18025. At least part of the sedimentary pile was sourced from these igneous rocks and the sediments were quickly buried, deformed, metamorphosed and uplifted before the intrusion of the Morro de Mejillones pluton took place at $208 \pm 2$ Ma. Rapid exhumation is suggested by the formation of andalusite in the contact aureole. The location of this basin in the continental margin remains unknown but it could well be a fore-arc basin or more probably an accretionary frontal wedge where similar fast processes of arc magmatism, erosion, sedimentation, burial, intermediate $\mathrm{P} / \mathrm{T}$ metamorphism and uplift have been recorded elsewhere (e.g., Matzel and Bowring, 2004; Ducea et al., 2009; Casquet et al., 2012).

The period between the Late Permian and the Late Triassic (Carnian), after the Gondwanide San Rafael orogeny, was essentially extensional along the pre-Andean continental margin, with abundant anorogenic silicic magmatism (part of the Choyoi group) and development of grabens oblique to the margin extending into Argentina. Apparently no subduction took place during this period (Charrier et al., 2007 and references therein).

The arguments produced here for burial of sedimentary rocks, the development of foliation and folding, Barrovian-type metamorphism and arc-magmatism in the Mejillones Peninsula suggest contractional deformation. We infer that this is evidence for renewed subduction along the continental margin in the Late Triassic.

\subsection{Source of detrital zircons}

Detrital zircons older than Triassic in the metasedimentary rocks from Mejillones Peninsula record many igneous events between 255 and $2700 \mathrm{Ma}$. The main peaks are Permian, Carboniferous, Ordovician and Cambrian, with sparse Proterozoic ages, many of them of Grenvillian age, i.e., between 0.9 and $1.3 \mathrm{Ga}$. Events corresponding to these ages are recognized in South America away from the Pacific margin (e.g., in the Sierras Pampeanas and the Cordillera Frontal of Argentina) and in the Andean basement. Thus detrital zircons of the metasedimentary rocks analysed here were either sourced from a foreland extending hundred of kilometres inland, or they were derived through cannibalization of older sedimentary rocks forming the basement of the ca. 210 Ma magmatic arc. The latter possibility is strengthened by evidence from Devonian to Permian turbidite sandstones accreted to the western margin of Gondwana in northern Chile in the late Paleozoic (Bahlburg et al., 2009). Detrital zircon age patterns from these rocks reflect all the orogenic cycles in western Gondwana between 2.0 and $0.25 \mathrm{Ga}$, as found in the Mejillones samples. Remarkably, a scarcity of Devonian zircons noted by Bahlburg et al. (2009) in the Paleozoic turbidites is also shown by the Mejillones rocks. This absence coincides well with the Devonian hiatus in magmatic activity in northern Chile indicated by Bahlburg and Hervé (1997) and interpreted as indicative of passive margin conditions at that time. 
Table 3

Summary of SHRIMP U-Pb zircon results for Mejillones igneous samples.

\begin{tabular}{|c|c|c|c|c|c|c|c|c|c|c|c|c|c|c|c|c|c|c|c|c|c|c|}
\hline \multirow[b]{2}{*}{ Grain spot } & \multirow[b]{2}{*}{$\begin{array}{l}\mathrm{U} \\
(\mathrm{ppm})\end{array}$} & \multirow[b]{2}{*}{$\begin{array}{l}\text { Th } \\
\text { (ppm) }\end{array}$} & \multirow[b]{2}{*}{$\mathrm{Th} / \mathrm{U}$} & \multirow[b]{2}{*}{$\begin{array}{c}{ }^{206} \mathrm{~Pb}^{\mathrm{a}} \\
(\mathrm{ppm})\end{array}$} & \multirow[b]{2}{*}{${ }^{204} \mathrm{~Pb} /{ }^{206} \mathrm{~Pb}$} & \multirow[b]{2}{*}{$\begin{array}{l}\mathrm{f}_{206} \\
\%\end{array}$} & \multicolumn{4}{|l|}{ Total ratios } & \multicolumn{6}{|c|}{ Radiogenic ratios } & \multirow[b]{2}{*}{$\rho$} & \multicolumn{5}{|l|}{ Age $(\mathrm{Ma})$} \\
\hline & & & & & & & ${ }^{238} \mathrm{U} /{ }^{206} \mathrm{~Pb}$ & \pm & ${ }^{207} \mathrm{~Pb} /{ }^{206} \mathrm{~Pb}$ & \pm & ${ }^{206} \mathrm{~Pb} /{ }^{238} \mathrm{U}$ & \pm & ${ }^{207} \mathrm{~Pb} /{ }^{235} \mathrm{U}$ & \pm & ${ }^{207} \mathrm{~Pb} /{ }^{206} \mathrm{~Pb}$ & \pm & & ${ }^{206} \mathrm{~Pb} /{ }^{238} \mathrm{U}$ & \pm & ${ }^{207} \mathrm{~Pb} /{ }^{206} \mathrm{~Pb}$ & \pm & $\%$ disc \\
\hline \multicolumn{23}{|c|}{ MEJ-18024 Morro Mejillones tonalite } \\
\hline 1.1 & 128 & 61 & 0.48 & 3.5 & 0.001274 & 0.20 & 31.80 & 0.52 & 0.0517 & 0.0017 & 0.0314 & 0.0005 & & & & & & 199.2 & 3.3 & & & \\
\hline 2.1 & 133 & 57 & 0.43 & 3.7 & 0.000210 & 0.34 & 30.91 & 0.49 & 0.0530 & 0.0017 & 0.0322 & 0.0005 & & & & & & 204.6 & 3.3 & & & \\
\hline 3.1 & 202 & 106 & 0.52 & 5.6 & 0.000342 & 0.60 & 30.88 & 0.44 & 0.0550 & 0.0014 & 0.0322 & 0.0005 & & & & & & 204.3 & 2.9 & & & \\
\hline 4.1 & 120 & 45 & 0.38 & 3.3 & 0.001109 & $<0.01$ & 31.33 & 0.51 & 0.0495 & 0.0022 & 0.0319 & 0.0005 & & & & & & 202.7 & 3.3 & & & \\
\hline 5.1 & 128 & 72 & 0.56 & 3.5 & 0.001299 & 0.01 & 31.71 & 0.51 & 0.0502 & 0.0017 & 0.0315 & 0.0005 & & & & & & 200.1 & 3.2 & & & \\
\hline 6.1 & 384 & 334 & 0.87 & 11.0 & 0.000005 & 0.10 & 30.05 & 0.38 & 0.0512 & 0.0010 & 0.0332 & 0.0004 & & & & & & 210.8 & 2.6 & & & \\
\hline 7.1 & 226 & 144 & 0.64 & 6.4 & 0.000037 & 0.40 & 30.16 & 0.37 & 0.0535 & 0.0012 & 0.0330 & 0.0004 & & & & & & 209.5 & 2.6 & & & \\
\hline 8.1 & 260 & 135 & 0.52 & 7.4 & 0.000089 & 0.28 & 30.02 & 0.36 & 0.0526 & 0.0010 & 0.0332 & 0.0004 & & & & & & 210.7 & 2.5 & & & \\
\hline 9.1 & 137 & 51 & 0.37 & 3.9 & 0.000486 & 0.19 & 30.19 & 0.43 & 0.0519 & 0.0013 & 0.0331 & 0.0005 & & & & & & 209.6 & 3.0 & & & \\
\hline 10.1 & 180 & 129 & 0.72 & 4.9 & 0.000407 & 0.11 & 31.31 & 0.40 & 0.0510 & 0.0011 & 0.0319 & 0.0004 & & & & & & 202.4 & 2.6 & & & \\
\hline 11.1 & 147 & 78 & 0.53 & 4.1 & 0.000207 & 0.23 & 30.80 & 0.41 & 0.0521 & 0.0013 & 0.0324 & 0.0004 & & & & & & 205.5 & 2.7 & & & \\
\hline 12.1 & 208 & 131 & 0.63 & 5.9 & - & 0.06 & 30.01 & 0.38 & 0.0509 & 0.0011 & 0.0333 & 0.0004 & & & & & & 211.2 & 2.6 & & & \\
\hline a 13.1 & 178 & 87 & 0.49 & 5.1 & 0.003249 & 7.01 & 29.74 & 0.47 & 0.1060 & 0.0026 & 0.0313 & 0.0005 & & & & & & 198.5 & 3.2 & & & \\
\hline 14.1 & 144 & 76 & 0.52 & 4.1 & 0.000567 & 0.36 & 30.55 & 0.43 & 0.0531 & 0.0014 & 0.0326 & 0.0005 & & & & & & 206.9 & 2.9 & & & \\
\hline 15.1 & 142 & 58 & 0.41 & 4.0 & 0.000012 & $<0.01$ & 30.26 & 0.43 & 0.0498 & 0.0014 & 0.0331 & 0.0005 & & & & & & 209.7 & 3.0 & & & \\
\hline 16.1 & 104 & 38 & 0.37 & 3.0 & 0.000912 & 0.32 & 30.16 & 0.46 & 0.0529 & 0.0015 & 0.0331 & 0.0005 & & & & & & 209.6 & 3.2 & & & \\
\hline 17.1 & 269 & 238 & 0.88 & 7.8 & 0.000270 & 0.24 & 29.73 & 0.37 & 0.0523 & 0.0009 & 0.0336 & 0.0004 & & & & & & 212.8 & 2.6 & & & \\
\hline 18.1 & 172 & 72 & 0.42 & 4.8 & 0.001058 & 0.53 & 30.57 & 0.41 & 0.0545 & 0.0012 & 0.0325 & 0.0004 & & & & & & 206.4 & 2.8 & & & \\
\hline 19.1 & 205 & 107 & 0.52 & 5.8 & 0.000468 & 0.20 & 30.32 & 0.40 & 0.0519 & 0.0011 & 0.0329 & 0.0004 & & & & & & 208.8 & 2.7 & & & \\
\hline 20.1 & 203 & 98 & 0.48 & 5.6 & 0.000165 & 0.24 & 31.19 & 0.41 & 0.0521 & 0.0018 & 0.0320 & 0.0004 & & & & & & 202.9 & 2.7 & & & \\
\hline \multicolumn{23}{|c|}{ Error in Temora reference zircon calibration was $0.62 \%$ for the analytical session. } \\
\hline \multicolumn{23}{|c|}{ MEJ-18029 Morro Jorgino garnet leucogranite } \\
\hline 1.1 & 138 & 48 & 0.34 & 24 & 0.000122 & 0.20 & 4.873 & 0.060 & 0.0812 & 0.0007 & 0.2048 & 0.0025 & 2.243 & 0.040 & 0.0794 & 0.0010 & 0.688 & 1201 & 13 & 1183 & 26 & -2 \\
\hline 2.1 & 223 & 153 & 0.69 & 12 & 0.000115 & $<0.01$ & 15.916 & 0.192 & 0.0544 & 0.0008 & 0.0628 & 0.0008 & & & & & & 392.9 & 4.7 & & & \\
\hline 3.1 & 112 & 24 & 0.22 & 16 & 0.000083 & 0.14 & 6.113 & 0.080 & 0.0752 & 0.0008 & 0.1634 & 0.0021 & 1.668 & 0.038 & 0.0741 & 0.0014 & 0.576 & 975 & 12 & 1043 & 37 & 6 \\
\hline 4.1 & 351 & 87 & 0.25 & 74 & 0.000014 & 0.02 & 4.103 & 0.046 & 0.0911 & 0.0005 & 0.2437 & 0.0027 & 3.053 & 0.038 & 0.0909 & 0.0005 & 0.904 & 1406 & 14 & 1444 & 10 & 3 \\
\hline 5.1 & 167 & 121 & 0.73 & 7 & 0.000826 & 0.59 & 21.231 & 0.295 & 0.0570 & 0.0012 & 0.0468 & 0.0007 & & & & & & 295.0 & 4.1 & & & \\
\hline 6.1 & 684 & 657 & 0.96 & 45 & 0.000048 & 0.16 & 13.076 & 0.143 & 0.0579 & 0.0005 & 0.0764 & 0.0008 & & & & & & 474.3 & 5.1 & & & \\
\hline 7.1 & 511 & 103 & 0.20 & 16 & 0.001571 & 3.17 & 28.331 & 0.327 & 0.0758 & 0.0017 & 0.0342 & 0.0004 & & & & & & 216.6 & 2.5 & & & \\
\hline 8.1 & 773 & 148 & 0.19 & 22 & 0.001880 & 3.52 & 30.578 & 0.360 & 0.0782 & 0.0013 & 0.0316 & 0.0004 & & & & & & 200.3 & 2.4 & & & \\
\hline 9.1 & 417 & 186 & 0.45 & 17 & 0.000065 & 0.16 & 21.614 & 0.253 & 0.0534 & 0.0007 & 0.0462 & 0.0005 & & & & & & 291.1 & 3.4 & & & \\
\hline 10.1 & 279 & 136 & 0.49 & 10 & 0.000018 & 0.02 & 24.510 & 0.314 & 0.0515 & 0.0010 & 0.0408 & 0.0005 & & & & & & 257.7 & 3.3 & & & \\
\hline 11.1 & 156 & 59 & 0.38 & 5 & 0.000261 & 0.39 & 28.404 & 0.424 & 0.0537 & 0.0014 & 0.0351 & 0.0005 & & & & & & 222.2 & 3.3 & & & \\
\hline 12.1 & 2948 & 32 & 0.01 & 71 & 0.000026 & 0.05 & 35.858 & 0.371 & 0.0500 & 0.0003 & 0.0279 & 0.0003 & & & & & & 177.2 & 1.8 & & & \\
\hline 13.1 & 340 & 216 & 0.63 & 23 & 0.000081 & 0.04 & 12.609 & 0.147 & 0.0574 & 0.0007 & 0.0793 & 0.0009 & & & & & & 491.8 & 5.6 & & & \\
\hline 14.1 & 3676 & 38 & 0.01 & 94 & 0.001109 & 1.93 & 33.509 & 0.348 & 0.0652 & 0.0007 & 0.0293 & 0.0003 & & & & & & 185.9 & 1.9 & & & \\
\hline 15.1 & 2953 & 326 & 0.11 & 76 & 0.000080 & $<0.01$ & 33.392 & 0.346 & 0.0498 & 0.0003 & 0.0299 & 0.0003 & & & & & & 190.2 & 2.0 & & & \\
\hline
\end{tabular}




$\begin{array}{lrrrrrrr}16.1 & 375 & 499 & 1.33 & 13 & 0.000340 & 0.06 & 24.876 \\ 17.1 & 5864 & 480 & 0.08 & 159 & 0.000146 & 0.13 & 31.773 \\ 18.1 & 1633 & 329 & 0.20 & 38 & 0.000510 & 0.97 & 36.512 \\ 19.1 & 8676 & 239 & 0.03 & 245 & 0.001102 & 1.92 & 30.480 \\ 20.1 & 2943 & 756 & 0.26 & 71 & 0.000091 & 0.09 & 35.363 \\ 21.1 & 3103 & 430 & 0.14 & 76 & 0.000519 & 0.96 & 35.016 \\ 22.1 & 3338 & 74 & 0.02 & 88 & 0.000611 & 0.51 & 32.427 \\ 23.1 & 4409 & 87 & 0.02 & 127 & 0.000614 & 0.68 & 29.851 \\ 24.1 & 3360 & 466 & 0.14 & 83 & 0.000172 & 0.25 & 34.785 \\ 25.1 & 2667 & 57 & 0.02 & 60 & 0.001033 & 1.93 & 37.958 \\ 26.1 & 1534 & 318 & 0.21 & 35 & 0.000236 & 0.33 & 37.642 \\ 27.1 & 8596 & 1130 & 0.13 & 230 & 0.000983 & 1.74 & 32.113 \\ 28.1 & 1170 & 74 & 0.06 & 29 & 0.000093 & 0.04 & 34.861 \\ 29.1 & 697 & 209 & 0.30 & 33 & 0.032305 & 58.03 & 18.116 \\ 30.1 & 1473 & 42 & 0.03 & 38 & 0.004136 & 7.96 & 32.989 \\ \text { Error in Temora reference zircon calibration was } 0.62 \% \text { for the analytical session. }\end{array}$

$\begin{array}{ll}0.299 & 0.0518 \\ 0.327 & 0.0512 \\ 0.388 & 0.0573 \\ 0.310 & 0.0655 \\ 0.366 & 0.0504 \\ 0.363 & 0.0573 \\ 0.349 & 0.0541 \\ 0.317 & 0.0558 \\ 0.360 & 0.0517 \\ 0.396 & 0.0648 \\ 0.402 & 0.0521 \\ 0.325 & 0.0639 \\ 0.377 & 0.0500 \\ 0.284 & 0.5120 \\ 0.353 & 0.1131\end{array}$

$0.0008 \quad 0.0402$

MEJ-18031 Cerro Moreno quartz diorite

\begin{tabular}{llllrlrl}
\multicolumn{7}{l}{ MEJ-18031 } & Cerro Moreno quartz diorite \\
1.1 & 310 & 351 & 1.13 & 7.6 & 0.000157 & 0.19 & 35.13 \\
2.1 & 232 & 179 & 0.77 & 5.9 & - & $<0.01$ & 33.99 \\
3.1 & 197 & 123 & 0.63 & 5.0 & 0.000369 & $<0.01$ & 34.04 \\
4.1 & 456 & 529 & 1.16 & 11.4 & 0.000078 & 0.14 & 34.24 \\
5.1 & 570 & 286 & 0.50 & 14.0 & - & 0.04 & 34.99 \\
6.1 & 358 & 368 & 1.03 & 8.9 & 0.000022 & 0.03 & 34.49 \\
7.1 & 683 & 712 & 1.04 & 17.2 & 0.000066 & 0.07 & 34.12 \\
8.1 & 248 & 181 & 0.73 & 5.5 & 0.000094 & $<0.01$ & 38.51 \\
9.1 & 578 & 691 & 1.20 & 14.3 & 0.000061 & $<0.01$ & 34.64 \\
10.1 & 443 & 484 & 1.09 & 11.0 & 0.000066 & 0.01 & 34.55 \\
11.1 & 254 & 211 & 0.83 & 6.4 & 0.000096 & 0.01 & 34.00 \\
12.1 & 381 & 202 & 0.53 & 9.4 & 0.000033 & 0.05 & 34.95 \\
13.1 & 257 & 299 & 1.16 & 6.3 & 0.000096 & 0.05 & 34.81 \\
14.1 & 690 & 898 & 1.30 & 17.1 & 0.000068 & $<0.01$ & 34.70 \\
15.1 & 715 & 446 & 0.62 & 17.8 & 0.000049 & 0.15 & 34.48 \\
16.1 & 248 & 230 & 0.93 & 6.2 & - & $<0.01$ & 34.58 \\
17.1 & 540 & 582 & 1.08 & 13.2 & 0.000076 & 0.03 & 35.15 \\
18.1 & 382 & 429 & 1.12 & 9.7 & 0.000094 & $<0.01$ & 33.78 \\
19.1 & 388 & 508 & 1.31 & 9.8 & 0.000109 & 0.04 & 33.98 \\
20.1 & 456 & 543 & 1.19 & 11.4 & - & 0.04 & 34.51
\end{tabular}

$\begin{array}{lllll}0.43 & 0.0512 & 0.0009 & 0.0284 & 0.0004 \\ 0.44 & 0.0494 & 0.0010 & 0.0294 & 0.0004 \\ 0.43 & 0.0494 & 0.0010 & 0.0294 & 0.0004 \\ 0.39 & 0.0509 & 0.0007 & 0.0292 & 0.0003 \\ 0.39 & 0.0500 & 0.0006 & 0.0286 & 0.0003 \\ 0.40 & 0.0500 & 0.0008 & 0.0290 & 0.0003 \\ 0.37 & 0.0504 & 0.0006 & 0.0293 & 0.0003 \\ 0.50 & 0.0488 & 0.0010 & 0.0260 & 0.0003 \\ 0.38 & 0.0497 & 0.0006 & 0.0289 & 0.0003 \\ 0.39 & 0.0499 & 0.0007 & 0.0289 & 0.0003 \\ 0.44 & 0.0499 & 0.0009 & 0.0294 & 0.0004 \\ 0.54 & 0.0501 & 0.0008 & 0.0286 & 0.0004 \\ 0.43 & 0.0501 & 0.0009 & 0.0287 & 0.0004 \\ 0.38 & 0.0494 & 0.0006 & 0.0288 & 0.0003 \\ 0.37 & 0.0509 & 0.0006 & 0.0290 & 0.0003 \\ 0.42 & 0.0496 & 0.0012 & 0.0289 & 0.0004 \\ 0.40 & 0.0500 & 0.0006 & 0.0284 & 0.0003 \\ 0.39 & 0.0498 & 0.0008 & 0.0296 & 0.0003 \\ 0.39 & 0.0501 & 0.0007 & 0.0294 & 0.0003 \\ 0.39 & 0.0501 & 0.0007 & 0.0290 & 0.0003\end{array}$

$\mathrm{f}_{206 \%}$ denotes the percentage of ${ }^{206} \mathrm{~Pb}$ that is common $\mathrm{Pb}$.

For areas older than $\sim 800 \mathrm{Ma}$ correction for common $\mathrm{Pb}$ was made using the measured ${ }^{204} \mathrm{~Pb} / 206 \mathrm{~Pb}$ ratio.

For areas younger than $\sim 800$ Ma correction for common Pb was made using the measured ${ }^{238} \mathrm{U} /{ }^{206} \mathrm{~Pb}$ and ${ }^{207} \mathrm{~Pb} /{ }^{206} \mathrm{~Pb}$ ratios following Tera and Wasserburg (1972) as outlined in Williams (1998).

a Indicates data not considered reliable (high-common $\mathrm{Pb}$ ). 


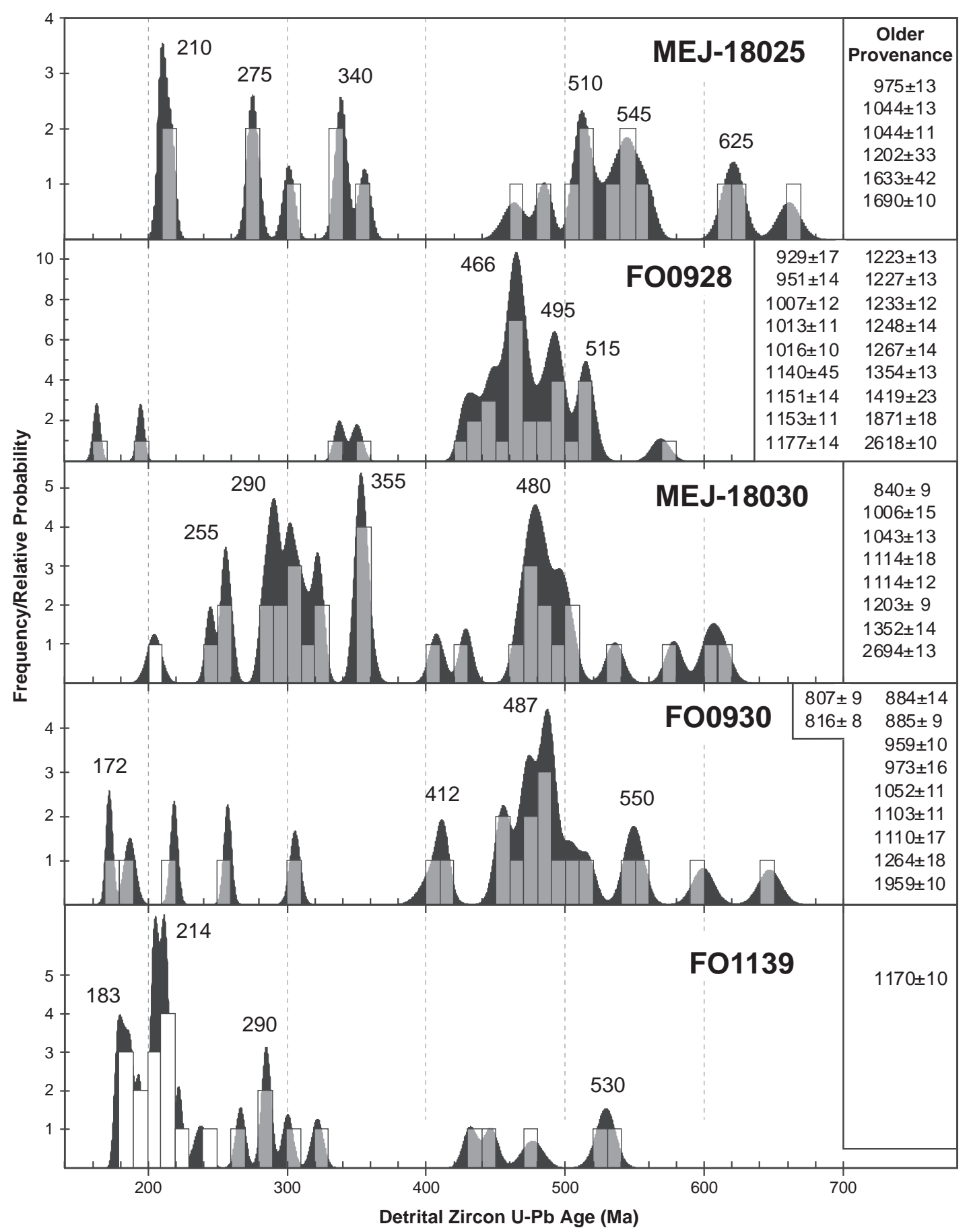

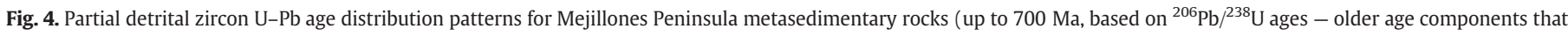

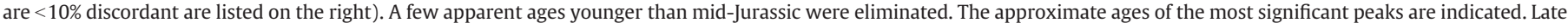
Triassic to Early Jurassic metamorphic rim ages are distinguished by solid white boxes in the histogram.

Permian zircons were probably sourced from the Choyoi province of mainly silicic volcanic rocks that is widespread in the Frontal Cordillera of Argentina. Llambias (1999) suggested that these rocks were erupted between ca. 260 and $247 \mathrm{Ma}$, but more recent $\mathrm{U}-\mathrm{Pb}$ zircon dating of southern parts of the complex shows a more precise age range of ca. 281 to 252 Ma (Rocha-Campos et al., 2011).

\subsection{The Jurassic magmatic arc}

A crystallization age of $184 \pm 1$ Ma was recorded for a diorite sample from the Bólfin-Punta Tetas igneous complex in the southern block, reasonably consistent with U-Pb zircon ages of $194 \pm 6$ and $191 \pm 6$ Ma from this same complex obtained by Damm et al. (1986); as reported by Cortés et al. (2007). The Bólfin-Punta Tetas igneous complex is thus a relic of an Early Jurassic magmatic arc that has an extensive development in northern Chile, where it is mainly represented by the La Negra Formation volcanic rocks (e.g., Scheuber and Gonzàlez, 1999), which started to be erupted in the Sinemurian. This magmatic event was probably responsible for the Pb-loss shown by the metamict overgrowths in leucogranite MEJ-18029 and banded schist FO1139, and for 190-140 Ma cooling ages found throughout the Mejillones Peninsula (Basei et al., 1996; Diaz et al., 1985; Lucassen et al., 2000). 

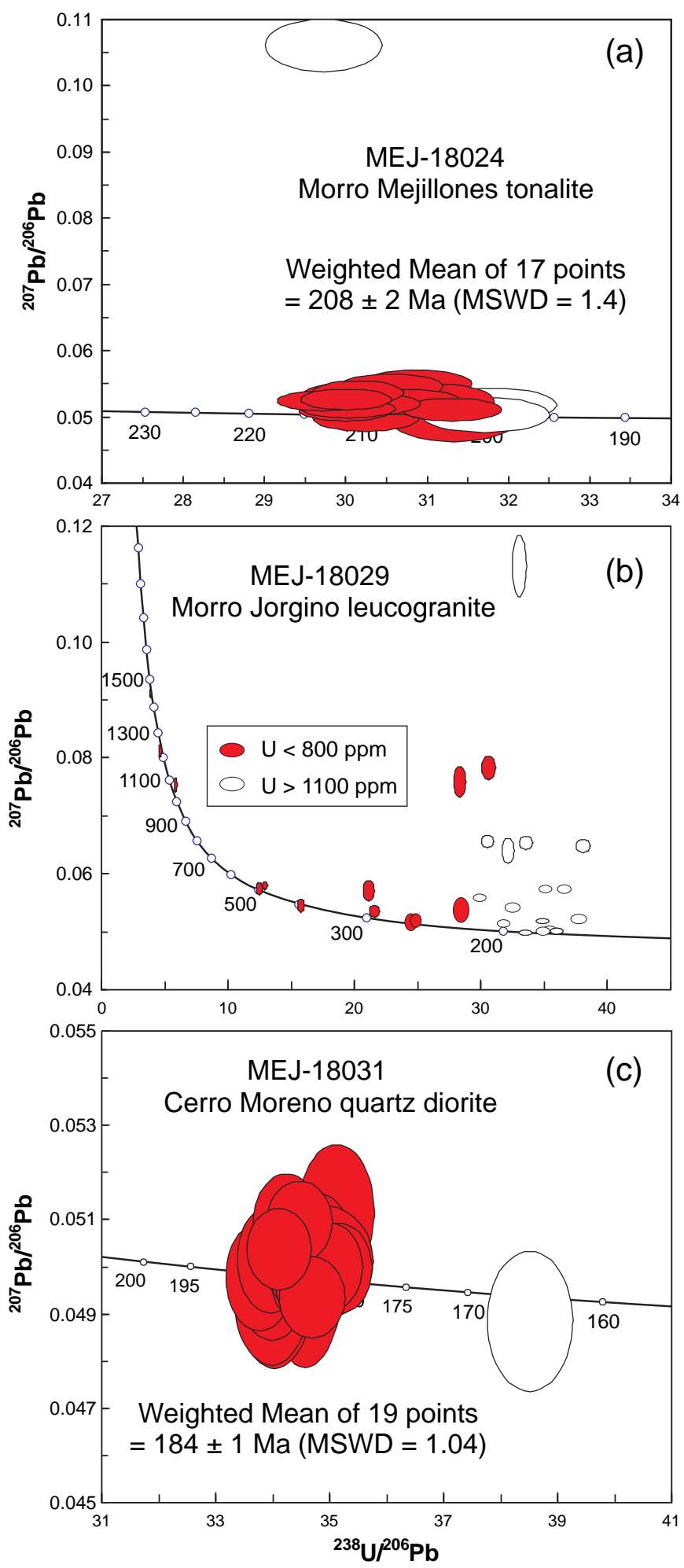

Fig. 5. Tera-Wasserburg plots of younger ages from zircons from the igneous rocks. Error ellipses are $68 \%$ confidence limits; white ellipses mark rejected points (in MEJ-18024 and MEJ-18031) and metamorphic rims (in MEJ-18029). NB. In accordance with the treatment of SHRIMP data in our previous publications and the original basis of this diagram (Tera and Wasserburg, 1972), the data are plotted without common- $\mathrm{Pb}$ correction so that deviation from the Concordia cannot be interpreted as discordance of the two U-Pb systems. The low count-rates for ${ }^{204} \mathrm{~Pb}$ do not allow precise correction of ${ }^{207} \mathrm{~Pb} /{ }^{235} \mathrm{U}$ ratios for low concentrations of ${ }^{207} \mathrm{~Pb}$, i.e., in young zircon with low-to-normal $\mathrm{U}$ contents; consequently our age estimates for zircon younger than ca. $800 \mathrm{Ma}$ is based on common $\mathrm{Pb}$ corrections using the measured ${ }^{238} \mathrm{U} /{ }^{206} \mathrm{~Pb}$ and ${ }^{207} \mathrm{~Pb} /{ }^{206} \mathrm{~Pb}$ ratio as in Williams (1998).

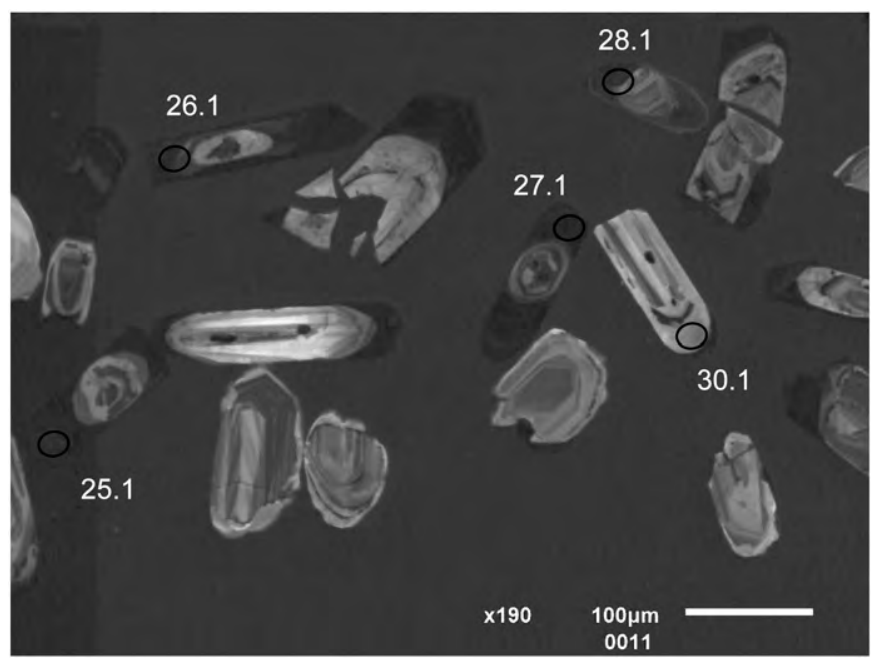

Fig. 6. CL image of MEJ-18029 showing grains exhibiting concentric igneous zonation, many of which have overgrowths with exceptionally high U contents (up to $8676 \mathrm{ppm}$ ), some of which are metamict.

Whether continuity existed between the Late Triassic magmatism (Morro Mejillones pluton) and the Bólfin-Punta Tetas Jurassic magmatic arc remains to be explored in more detail, as no intermediate ages have been recorded so far to our knowledge. However, evidence for annealing processes of Early Jurassic age recorded in the Late Triassic metamorphic and igneous rocks of Mejillones peninsula suggests that the latter were probably host to the Early Jurassic magmatic arc.

Remarkably, paleomagnetic data from Mejillones Peninsula indicates that no significant large scale latitudinal translation has taken place since the Jurassic (Hartley et al., 1992). The peninsula and the Bólfin area to the south were probably part of the same displaced block along the Atacama Fault system.

\section{Conclusions}

The Mejillones Peninsula is a composite block of Late Triassic (Norian) metamorphic and igneous rocks, and of Early Jurassic (Pliensbachian) plutons that reached its present position by displacement probably along the Atacama Fault system of northern Chile in the Jurassic and Early Cretaceous. Earlier suggestions of an Early Paleozoic metamorphism are not confirmed and are considered highly suspect.

The Mejillones metamorphic and igneous basement represents the end of the Late Permian to Late Triassic (Carnian) anorogenic cycle and the renewal of subduction and arc-magmatism along the pre-Andean continental margin in the Late Triassic (Norian). Relationships of this geodynamic event with the Early Jurassic Bólfin-Punta Tetas magmatic arc remain unknown.

Because the tectonostratigraphic evidence is markedly different on both sides of the Atacama fault system (e.g., Limón Verde) we suggest that the inferred status of Mejillonia as a transcurrent terrane (see Gibbons, 1994) be retained.

\section{Acknowledgements}

This research is a combined effort of projects CGL 2009-07984 (former Spanish Ministry of Science \& Innovation); PIP CONICET 1940; BID 1728/OC AR PICT 1009 (Argentina) and FONDECYT 1095099 (Chile). A. Jensen (Universidad Catòlica del Norte) provided the geographical clues to identify the only road to access the top of Morro Jorgino block. Prof. Hans Massonne, Stuttgart University participated in one of the field trips. Juan Vargas (Universidad de Chile) separated the zircons. Carmen Galindo, Universidad Complutense, helped with 
constructive comments and with the handling of figures. Mauricio Ibañez-Mejía and an anonymous referee are acknowledged for their helpful comments that helped to improve the manuscript.

\section{References}

Baeza, L., 1984. Petrography and Tectonics of the Plutonic and Metamorphic Complexes of Limon Verde and Mejillones Peninsula, Northern Chile. (Unpublished thesis) Eberhard Karls University Tübingen, Germany.

Bahlburg, H., Hervé, F., 1997. Geodynamic evolution and tectonostratigraphic terranes of northwestern Argentina and northern Chile. Bulletin of the Geological Society of America 109, 869-884.

Bahlburg, H., Vervoort, J.D., Du Frane, S.A., Bock, B., Augustsson, C., Reimann, C., 2009. Timing of crust formation and recycling in accretionary orogens: insights learned from the western margin of South America. Earth-Science Reviews 97, 215-241.

Basei, M.A.F., Charrier, R., Hervé, F., 1996. New ages (U-Pb, Rb-Sr, K-Ar) from supposed pre-Cambrian units in northern Chile: some geotectonic implications. Third International Symposium on Andean Geodynamics, pp. 763-766 (Saint Malo, France, Extended abstracts)

Brown, M., Diaz, F., Grocott, J., 1993. Displacement history of the Atacama fault system $25^{\circ} 00$ S-27 $00^{\prime}$ S, northern Chile. Geological Society of America Bulletin 105, 1165-1174.

Casquet, C., Rapela, C.W., Pankhurst, R.J., Baldo, E., Galindo, C., Fanning, C.M., Dahlquist, J., 2012. Fast sediment underplating and essentially coeval juvenile magmatism in the Ordovician margin of Gondwana, Western Sierras Pampeanas, Argentina. Gondwana Research 22, 664-673.

Cawood, P.A., Kröner, A., Windley, B., 2003. Accretionary orogens: definition, character, significance. European Geophysical Society. Geophysical Research Abstracts 5, 04856.

Cawood, P.A., Kröner, A., Collins, W.J., Kusky, T.M., Mooney, W.D., Windley, B.F., 2009. Accretionary orogens through Earth history. In: Cawood, P.A., Kröner, A. (Eds.) Earth Accretionary Systems in Space and Time: Geological Society of London, Special Publications, 318, pp. 1-36.

Charrier, R., Pinto, L., Rodriguez, M.P., 2007. Tectonostratigraphic evolution of the Andean Orogen in Chile. In: Moreno, T., Gibbons, W. (Eds.), The Geology of Chile. The Geological Society, London, pp. 21-114.

Cortés, J.C., Marquardt, C.R., González, G.L., Wilke, H-G.H., Marinovic, N., 2007. Carta Mejillones y Península Mejillones. Región de Antofagasta. Carta Geológica de Chile 1:100.000, SERNAGEOMIN, Santiago.

Cortés, J., Rémy, D., González, G., Martinod, J., Gabalda, G., 2008. Fractures in the Mejillones Península triggered by the Tocopilla $\mathrm{Mw}=7.7$ earthquake. 7th International Symposium on Andean Geodynamics (ISAG 2008, Nice), pp. 168-171 (Extended Abstracts).

Damm, K.W., Pichowiak, S., Todt, W., 1986. Geochemie, petrologie und geochronologie der plutonite un des metamorphen Grundgebirges in NordChile. Berliner Geowissenschaftliche Abhandlungen, A/66, 73-146.

Damm, K.W., Pichowiak, S., Harmon, R.S., Todt, W., Kelley, S., Omarini, R., Niemeyer, H., 1990. Pre-Mesozoic evolution of the Central Andes, the basement revisited. Geological Society of America, Special Paper 241, 101-126.

Diaz, M., Cordani, U., Kawashita, K., Baeza, L., Venegas, R., Hervé, F., Munizaga, F., 1985. Preliminary radiometric ages from the Mejillones Peninsula, Northern Chile. In: Hervé, F., Munizaga, F. (Eds.), Evolución Magmática de los Andes. : Comunicaciones, 35. Departamento de Geología, Universidad de Chile, Santiago, pp. 59-67.

Ducea, M.H., Kidder, S., Chesley, J.T., Saleeby, J.B., 2009. Tectonic underplating of trench sedimentes beneath magmatic arcs: the central California example. International Geology Review 51, 1-26.

Gibbons, W., 1994. Suspect terranes. In: Hancock (Ed.), Continental Deformation. Pergamon Press, Oxford, pp. 305-319.

Hartley, A., Turner, P., Rex, D.C., Flint, S., 1992. Paleomagnetic, geochronological and geological constraints on the tectonic evolution of the Mejillones Peninsula, northern Chile. Geological Journal 27, 59-74.
Hartley, A.J., May, G., Chong, G., Turner, P., Kape, S.J., Jolley, E.J., 2000. Development of continental forearc: a Cenozoic example from the Central Andes, Northern Chile. Geology 28, 331-334.

Hervé, F., Mpodozis, C., 1990. Terrenos tectonoestratigráficos en la evolución geológica de los Andes chilenos: una revisión. Actas, XI Congreso Geológico Argentino, II. Asociación Geológica Argentina, San Juán, Argentina, pp. 319-323.

Hervé, F., Massonne, H.-J., Calderón, M., Soto, F., Fanning, C.M., 2010. Pre-Mesozoic metamorphism and tectonics in northern Chile: collisional vs. subduction zone environments. Eos, Transactions of the American Geohpysical Union 91 (26) (Meeting of the Americas Supplement, Abstract V11A-04)

Llambias, E.J., 1999. Las rocas ígneas gondwánicas. 1. El magmatismo gondwánico durante el Paleozoico Superior - Triásico. Geología Argentina: Anales del Instituto de Geología y Recursos Minerales, Buenos Aires, 29, pp. 349-363.

Lucassen, F., Becchio, R., Wilke, H.G., Franz, G., Thirlwall, M.F., Viramonte, J., Wemmer, K. 2000. Proterozoic-Paleozoic development of the basement of the Central Andes $\left(18-26^{\circ}\right)$. A mobile belt of the South American craton. Journal of South American Earth Sciences 13, 697-715.

Ludwig, K.R., 2001. SQUID 1.02. A user's manual: Berkeley Geochronological Center Special Publication, 2, 2455 Ridge Road, Berkeley, Ca 94709, USA.

Matzel, J.E.P., Bowring, S.A., 2004. Protolith age of the Swakane Gneiss, North Cascades, Washington: evidence of rapid underthrusting of sediments beneath an arc. Tectonics 23, TC6009. http://dx.doi.org/10.1029/2003TC001577 (18 pp.).

Mezger, K., Krogstad, E.J., 2004. Interpretation of discordant U-Pb zircon ages: an evaluation. Journal of Metamorphic Geology 5, 127-140.

Niemeyer, H., González, G., Martínez-De los Rios, E., 1996. Evolución tectónica cenozoica del margen continental activo de Antofagasta, norte de Chile. Revista Geológica de Chile 23, 165-186

Ramos, V.A., 1988. Late Proterozoic-Early Paleozoic of South America. A collisional history. Episodes 11, 168-174.

Rapela, C.W., Pankhurst, R.J., Casquet, C., Baldo, E., Saavedra, J., Galindo, C., Fanning, C.M., 1998. The Pampean orogeny of the southern Proto-Andes: a Cambrian continental collision. Evidence from the Sierras Pampenas de Cordoba (Argentina). Geological Society of London, Special Publications 142, 181-217.

Rocha-Campos, A.C., Basei, M.A., Nutman, A.P., Kleimann, L.E., Varela, R., Llambías, E. Canile, F.M., da Rosa, O. de C.R., 2011. 30 million years of Permian volcanism recorded in the Choiyoi igneous province (W Argentina) and their source for younger ash fall deposits in the Paraná Basin: SHRIMP U-Pb zircon geochronology evidence. Gondwana Research 19, 509-523.

Scheuber, E., Gonzàlez, G., 1999. Tectonics of the Jurassic-Early Cretaceous magmatic arc of the north Chilean Coastal Cordillera $\left(22^{\circ}-26^{\circ} \mathrm{S}\right)$ : a story of crustal deformation along a convergent plate boundary. Tectonics 18, 895-910.

Stern, C.R., 2011. Subduction erosion: rates, mechanisms, and its role in arc magmatism and the evolution of the continental crust and mantle. Gondwana Research 20, 284-308.

Tera, F., Wasserburg, G., 1972. U-Th-Pb systematics in three Apollo 14 basalts and the problem of initial $\mathrm{Pb}$ in lunar rocks. Earth and Planetary Science Letters 14, 281-304.

Tomlinson, A.J., Blanco, N., García, M., Baeza, L., Alcota, H., Ladino, M., Pérez de Arce, C. Fanning, C.M., Martin, M.W., 2012. Permian Exhumation of Metamorphic Complexes in the Calama Area: Evidence for Flat-Slab Subduction in Northern Chile During the San Rafael Tectonic Phase and Origin of the Central Andean Gravity High. XIII Congreso Geológico Chileno, Antofagasta, Electronic Expanded Abstracts, thematic Session T2, pp. 209-211.

Williams, I.S., 1998. U-Th-Pb geochronology by ion microprobe. In: McKibben, M.A., Shanks III, W.C., Ridley, W.I. (Eds.), Applications of Microanalytical Techniques to Understanding Mineralizing Processes: Reviews of Economic Geology, 7 pp. 1-35. 